\title{
ANYONE FOR A GAME OF MONOPOLY'TM?* A CRITICAL EVALUATION OF THE EVER- INCREASING COMMERCIALIZATION OF MAJOR SPORTING EVENTS PART 2: EXAMINING THE LEGITIMACY OF THE CREATION AND MAINTENANCE OF COMMERCIALLY-DRIVEN MONOPOLIES IN SPORTS EVENTS
}

Andre $\mathrm{M}$ Louw $^{* *}$

$B A$ LLB LLM

Faculty of Law

University of KwaZulu-Natal, Durban

\section{SUMMARY}

This is the second part of an article published in three parts that critically examines the commercial monopolisation of sporting mega-events such as the FIFA football World Cup, and of commercial rights protection of such events. The first part of this article contained mainly a descriptive overview of ambush marketing and of the legal and other measures available to event organisers and sponsors to combat such practices. This second (and the forthcoming third) part of the article will continue to critically evaluate the legitimacy of a prime source of protection for these commercial actors, namely anti-ambush marketing legislation, with a specific focus on the South African jurisdiction and the 2010 FIFA World Cup South Africa.

"[W]here does protection against ambush marketing fit into general anti-trust legislation? Effectively, sponsors are paying to obtain a monopoly. There has been very little consideration of the relationship between the demands for extended protection and competition principles. Not surprisingly, the issue has been raised only by governments and public bodies, not by sports organizations.

With apologies to US trademark holders Parker Bros. and John Waddington Ltd (licensed manufacturers and distributors of the Monopoly ${ }^{\mathrm{TM}}$ board game outside the USA).

** Parts of this article are based on or include material previously published in the author's monograph on "South Africa", in the series International Encyclopaedia of Sports Law 
As the foundations of intellectual property law are based on the grant of some form of monopoly, the extension of such protection should not happen on demand. Big business, in the guise of sports organizations, is not entitled to unwarranted protection for descriptive words merely because this is 'good for the game'. Neither is it entitled to prevent others from expressing pleasure and interest in the very 'game' on which its demands are based."

"Supporters of ambush marketing ... see it as smart business. Arguably, ambush marketing provides a positive free market force. By exposing to official sponsors and event organizers the true scope of exclusivity that any sponsor can reasonably expect to enjoy, ambushers in effect help quantify the true market value of Olympic [or other major event] sponsorship ... Critics ... would suggest that the threat of ambush marketing could ultimately impair the ability of event organizers to host elaborate and successful Olympic Games if ambush marketing deters large multinational corporations from being official sponsors. However, the appeal to large corporations of the world-wide exposure that results from sponsorship of the Olympic Games will never be diminished by market imperfections such as ambushers to the point of threatening the budgets of event organizers."

\section{INTRODUCTION: THE CREATION OF COMMERCIAL MONOPOLIES IN SPORTING EVENTS}

The first part of this article ${ }^{4}$ examined, on a largely descriptive level, the practices of ambush marketing of sports events and the legal bases for protection against those engaged in such practices. To coin a phrase, some observers have likened such conduct to what amounts to proverbial "wedding crashing", ${ }^{5}$ and it can definitely provide more than just irritation to

Kluwer Law International (September 2009) ISBN 978-90-411-1754-0 - reproduced here with the permission of the publishers, Kluwer Law International BV, The Netherlands.

I wish to thank my colleague Tanya Woker sincerely for her kind comments on an earlier draft of this article, for taking the time to discuss related issues and for sharing a sentiment of dubious suspension of disbelief in respect of some of the issues and developments relating to the hosting of the 2010 FIFA World Cup as referred to in this article. I also wish to thank Jo-Ann du Plessis for her invaluable and insightful editorial assistance with an advanced draft of this article.

Kelbrick "Ambush Marketing and the Protection of the Trade Marks of International Sports Organizations - A Comparative View" 2008 41(1) CILSA 2448.

2 Ibid.

3 Schmitz "Ambush Marketing: The Off-field Competition at the Olympic Games" Spring 2005 3 Northwestern Journal of Technology \& Intellectual Property 203 - http://www.law. northwestern.edu/journals/njtip/v3/n2/6/.

4 Published as Louw and Areias "Anyone for a Game of Monopoly? A Critical Evaluation of the Ever-increasing Commercialisation of Major Sporting Events: Part 1: An Overview of Ambush Marketing in Sport" 201031 1 57-91.

5 Scaria Ambush Marketing: Game Within a Game (2008) observes the following in the preface:

"An ambush marketer is an uninvited guest to a sponsored event. As the very term indicates, ambush marketing is a type of marketing wherein non-sponsors make startling appearances in a sponsored event to give an impression of involvement, without formally associating with the event and committing to the financial liabilities involved in it. Needless to say, such apparent involvement and the fallacious impression created by it can have devastating consequences, not only for the sponsors but also for the event organisers. Sponsorship is one of the most important sources of income for event organisers across the world and for the corporate world it is a befitting conduit for promoting their brands. However, it is certain that the 
official sponsors and event organizers. ${ }^{6}$ However, in the spirit of attempting to avoid the indiscriminate painting of alleged "ambush marketers" with an overly-broad brush - and at the risk of displaying a lack of objectivity on the issues - it is the purpose of this sequel to evaluate critically, from a legal perspective, the measures that have been employed to date to counter such seemingly illegitimate practices in order to protect the commercial interests of those involved in the staging of major sports events. In fact, and more fundamentally, it is my intention to examine the very legitimacy of the trend towards creating commercial monopolies in such events as well as the increasingly expansive legislative legitimization of such monopolies.

This second part of this article will consider potential intellectual property law and competition law challenges to such commercial monopolies in mega-events, and will commence a Bill of Rights-based evaluation (with specific reference to the constitutionally protected freedom of expression guarantee) of the legitimacy of such monopolies and of the legislative and other measures that are employed to maintain such monopolies. The forthcoming third and final part of this article will conclude this evaluation (with reference to the constitutionally protected freedom of trade, occupation and profession and the right to property), and will proceed to

- evaluate the arguments raised by sports governing bodies in justification of such monopolies;

- examine recent FIFA-driven anti-ambush marketing litigation in South Africa in respect of the 2010 FIFA World Cup event; and

- examine relevant developments in respect of a "sports event organizers' right" in other jurisdictions.

The forthcoming Part 3 of this article will conclude with some remarks regarding the dangers of the current treatment of these issues in our law.

The modern era has seen an apparent world-wide backlash against some of the more invidious aspects of capitalism and free markets, especially anticompetitive behaviour. In South Africa and elsewhere competition legislation has been adopted (for example, the South African Competition $\mathrm{Act}^{7}$ ) and, specifically in this jurisdiction in recent years, the competition authorities and others (for example, the Independent Communications Authority of SA, or

sponsorship potential will dwindle if the exclusivity of association with an event is not suitably protected."

This last assumption is, of course, not as open and shut as the author might suggest; this article will consider divergent views in this regard.

6 Eg, in preparation for the 2004 Athens Olympic Games more than USD 750000 was spent removing and cleaning billboards throughout the city, in an effort to prevent non-sponsors from grabbing the limelight during the event. Nike is often cited as an example of a major multinational corporation that apparently has few scruples when it comes to "ambushing" their competitors in respect of sporting events: The company has been credited with having its own "director of ambush marketing", and during the 1996 Atlanta Olympic Games it not only produced a commercial web site (Nike@Lanta) but also erected its name and logo on a building overlooking Atlanta's Olympic Park - the building was apparently constructed specifically for the purpose of ambush marketing! - see Shank Sports Marketing: $A$ Strategic Perspective (1999) 373-374.

7 Act 89 of 1998 - see the discussion in par 22 below. 
ICASA) have played an ever more visible and significant role in clamping down on cartels and monopolies and in addressing abuse of dominance by firms and undertakings, ranging from bread manufacturers to cell-phone service providers, in the interests of consumers. Sport has, at least in other jurisdictions if not in South Africa to date, not failed to escape the scrutiny of competition authorities, and those who abhor the abuse of power by those with significant commercial clout should seriously consider the legitimacy of the conduct of organizations or commercial entities that so often claim promotion of the common good as a veiled attempt to justify the baser generation of profits.

The main focus areas of this article, namely anti-ambush marketing measures and the often rabid protection of exclusive commercial interests in sporting events, are at the crossroads of the interaction between such developments in competition law and other fields of law. A significant aspect of the fight against ambush marketing involves the use of intellectual property (or IP) rights; ${ }^{8}$ and these rights are, traditionally, fundamentally about the creation of (limited) monopolies. ${ }^{9}$ It is hoped that the irony in the reference to the phenomenally successful Monopoly ${ }^{\mathrm{TM}}$ board game in the title of this article is not lost on the reader - through the working of intellectual property law even the word "monopoly" has been monopolized to the extent of the applicable trademark protection!

A further aspect that requires special consideration is the fact that such issue of monopolization of sporting events by means of (for example) antiambush marketing measures is, in the sporting context, situated squarely within an inherently monopoly-based global industry. I have elsewhere discussed the fundamental monopolistic governance role and functions of (international) sports governing bodies in terms of the "European Model of Sport", and have characterized these organizations as monopoly regulators with inherent market dominance. While "monopolization" of major sporting events might, therefore, appear to be a natural consequence or function of the very milieu within which these organizations operate, it must be remembered that recent years have seen the development of an increasingly strained dichotomy between the commercial function of sports organizations and their traditional role as "custodians of the game" in the respective sports, in the (at least professed) interests of the public. I have also discussed this issue in more detail elsewhere, and the reader is simply requested to bear this in mind in considering the discussion that follows.

It is contended that the ever-increasing efforts at commercialization of major events by sports governing bodies and their commercial partners are

See the discussion in par 225 of Part 1 of this article.

As it has been put, succinctly, in the American context:

"Both patent and copyright law limit competition and therefore increase or at least stabilize prices for a product or service. Patents and copyrights are the only constitutionally mandated monopolies, created with the recognition that unfettered competition would drain creators of their financial incentive to create."

Vaidhyanathan Copyrights and Copywrongs: The Rise of Intellectual Property and How it Threatens Creativity (2003) 87. 
fostering a culture of greed and opportunism surrounding such events, which is inimical to the very raison d'etre for the events and their traditional role of providing a showcase to the public of the best in sporting talent and athletic endeavours. While, for example, much has been made promotionally in recent years of football as the "beautiful game", and while the status of football as the game of the people has often been touted - especially with reference to the African continent - FIFA's much-celebrated first foray onto African soil with the 2010 FIFA World Cup South Africa ${ }^{\text {TM }}$ has, already prior to the event, been characterized by apparently deep-seated apathy for the interests of the masses and, frankly, apparent attempts (not only by FIFA and its commercial partners but also by other service providers) to simply milk the commercial potential of the popularity of the event for all its worth. Examples range from controversy surrounding ticket-pricing by FIFA $^{10}$ to a current (at the time of writing) investigation by South African competition authorities into allegations of collusion by the country's major airlines in hiking airfares with a view to the event, ${ }^{11}$ as well as reports of exorbitant rates set by private accommodation service providers threatening the potential uptake by foreign tourists for the event. While such apparently short-sighted scrambling for what will surely promise to be no more than short-term gains may be understandable in respect of small businesses, the more systemic and institutionalized pursuit of profit associated with the commercial arrangements of major sports governing bodies and their multimillion dollar sponsors and partners is much more worrying.

The attempts to protect the commercial rights and interests associated with major events, as discussed in this article, relate to two legal bases: The first is intellectual property protection in respect of licensing schemes involving the intellectual properties created for and associated with such events (primarily registered trademarks and copyrighted works, and ranging from official marks, emblems and event posters to mascots and event anthems). The second relates to purely contractual rights created between sports governing bodies and their commercial partners, rights that are enforceable only between such contracting parties in light of the privity of contract. These rights are the genesis of sponsorship exclusivity in relation

10 FIFA is no stranger to controversy surrounding the sale of tickets to its World Cup events. The European Competition Commission ruled against the French local organising committee (the CFO) established by FIFA and the French football federation for purposes of the hosting of the 1998 FIFA World Cup in France, in respect of its mandate in respect of ticket sales. The Commission ruled that the CFO had infringed Article 82 of the EC Treaty (see discussion in the text below) by applying discriminatory arrangements in the sale of tickets to the general public, which involved the imposition of unfair trading conditions on consumers outside France which resulted in the limitation of the market to the prejudice of such consumers - Commission Decision of 20 July 1999, Case IV/36.888 - 1998 Football World Cup); see the discussion in Gardiner, James, O'Leary and Welch Sports Law 3ed (2006) 360-362; and see also fn 83 below.

11 It was reported on 7 April 2010 that competition authorities had raided the offices of South African Airways and its low-cost local subsidiary Mango Airlines in order to obtain evidence in respect of such collusion investigation (and it was speculated that these two companies were at risk of losing indemnity for their participation in such investigation on the basis of alleged withholding of evidence). 
to events. ${ }^{12}$ The discussion that follows will evaluate the legitimacy of the measures used to protect these rights, especially in respect of such measures' consequences for outside parties and the public at large.

In essence, the commercial arrangements surrounding a major event such as the football World Cup or Olympic Games involve a monopoly regulator of the commercial rights associated with such an event (for example, FIFA, the sole rights holder and regulator in respect of the football competition, in terms of rights claimed in the organization's founding documents ${ }^{13}$ ) inviting bids from would-be sponsors or broadcasters to obtain rights to associate with or to broadcast the event to the exclusion of all others. ${ }^{14}$ In passing, it should be noted that the bid processes in respect of commercial rights to major events are not always transparent and have, allegedly, at least once in the past been manipulated in an apparently anticompetitive manner by FIFA executives in respect of the football World Cup. ${ }^{15}$ It has also been reported that Match Event Services, which is FIFA's exclusive official accommodation provider for the 2010 World Cup and no stranger to controversy, was apparently appointed without any tender process. ${ }^{16}$

12 As has been observed: "Simply put, [sponsorship] exclusivity is difficult to control, but it would be impossible without contractual stipulations." Graham, Goldblatt and Delpy The Ultimate Guide to Sport Event Management and Marketing (1995) 103.

13 Compare Article 74 of the FIFA Statutes (August 2009 version, currently in force at the time of writing), and discussion in par 221 in Part 1 of this article. See also the description of FIFA in the preamble to the 2010 FIFA World Cup South Africa By-laws as published by the eThekwini Municipality for the host city of Durban (see discussion elsewhere in this article), which describes FIFA as "both the world governing body of association football and the lawful owner of the world-wide Marketing Rights, Media Rights and all other commercial rights in respect of the [World Cup] Competition". Such description does, of course, not qualify such "rights" in respect of their nature and status (ie, the personal nature - read: unenforceability against third parties - of contractual rights flowing from commercial agreements with sponsors).

14 Gardiner et al 458 explain the value of sports sponsorship for sponsors as follows:

"[T]he sponsor's association is with the sponsored party's sports event and also with the emblems, logos and mascots (the event marks) that identify and distinguish the particular sports body and its event ... Sports sponsorship results in a transfer of the essential values and properties of the sponsored party and its events to the sponsor's business organisation and, ultimately, to its products and/or services, thereby raising the sponsor's profile and standing in the community (offering public relations opportunities and advantages) and amongst its existing and potential customers ... [The value of sports sponsorship] also lies in the fact that the sponsor is given exclusivity in the particular product or service category in respect of which the sponsorship rights are granted by the owner of the rights."

15 See discussion of the bid process for the sale of television broadcasting rights to the 2002 and 2006 FIFA World Cups in Jennings Foul! The Secret World of FIFA: Bribes, Vote Rigging and Ticket Scandals (2006) Chapter 7.

16 Rose "FIFA'S 'Official' Suppliers: Shadowy Tenders and Conflicts of Interest at Match" in Schulz-Herzenberg (ed) Player and Referee: Conflicting Interests and the 2010 FIFA World Cup $^{T M}$ (April 2010) Monograph 169, Institute for Security Studies writes as follows (99-100): "While [Match Event Services] officially warns accommodation providers to keep room rates low because tourists are 'sensitive to pricing', an investigation by the author has confirmed that tourists will have to pay Match 1000 per cent more than they would normally pay for accommodation in certain cases, such as for units at South Africa's Kruger National Park. Match Event Services is owned entirely by a family-owned UKregistered company called Byrom PLC. The circumstances of its appointment remain 
Through such bidding processes large multinational corporations that are able to afford the very substantial rights fees enter into agreements with the organization which effectively close the market (and often for a long period of time ${ }^{17}$ ) to all non-sponsors, for example, also small business entities in the particular country or geographical area where the event is to be hosted, which entities are rarely able to compete on a level playing field (or at all) with the official sponsors and commercial partners in terms of the financial outlay required by the sports organization. By way of example, it has been observed that sponsors who participate in the TOP ("The Olympic Partner") programme, which is the highest level of Olympic sponsorship that gives sponsors the right to sponsor one quadrennial cycle of the Winter and Summer Games, invest between USD 200-300 million for the privilege (with the sponsorship fee amounting to more than USD 70 million and a further investment of between three and four times that amount in activation expenditures such as marketing programmes to give effect to the sponsorship, for an event that lasts just over two weeks). ${ }^{18}$ Accordingly, and in common parlance, what may be compared to a very exclusive and elite "old boys' club" is created to profit from the event, and the interests of the members of such club are vigorously protected by (ever-increasingly rigid ${ }^{19}$ ) legislation and other anti-ambush marketing measures in the host country. Such legislation is obtained through pressure by the sports organization on the host government by means of rigid requirements related to the provision of guarantees in the bidding process. ${ }^{20}$ For example, in the 2010 football

cloudy: there was never any public tender for the multi-million rand contract, for example. Riding on those coat-tails is the closely linked Match Hospitality, which has FIFA's official stamp of approval to provide exclusive hospitality packages to large companies seeking to impress clients at the South African event. Not only does Match Hospitality refuse to disclose its exact shareholding structure, but it has emerged that one of the four shareholders in the company is Infront Sports \& Media, a company headed by Philippe Blatter - nephew and godson of the FIFA supremo."

17 Organizations such as the International Olympic Committee and FIFA enter into long-term contracts which span multiple major events with their most attractive high profile sponsors (eg, VISA is currently involved in a long-term agreement with FIFA as a "FIFA Partner" in the financial services segment until the year 2014; Coca-Cola earlier entered into a 16-year deal with FIFA at a cost of USD 500 million).

18 Davis The Olympic Games Effect: How Sports Marketing Builds Strong Brands (2008) 161 163.

19 Compare the voluminous Major Sporting Events Bill 2009 of the Parliament of Victoria in Australia (the status of which in the legislative process is at the time of writing unknown to the author). This document runs to over 200 sections, dealing with safety at sporting events, ambush marketing, ticketing, etc. By way of illustration of the types of ambush marketing conduct prohibited by this Bill, compare the wording of $s 38$, which provides that it is an offence for a person to use protected event logos or images or protected event references without authorization, if such use would (inter alia) "suggest a sponsorship-like arrangement to a reasonable person" (s 38(1)(e) of the Bill).

20 The New Zealand Rugby Football Union failed to secure co-hosting rights to the 2003 IRB Rugby World Cup due to its inability to guarantee "clean stadia" for the event to the IRB. As part of New Zealand's successful bids to host the 2011 Rugby World Cup and the 2015 ICC Cricket World Cup a commitment was given to ensure adequate provisions were in place to protect sponsors. New Zealand subsequently passed much-criticised and very extensive anti-ambush marketing legislation in the form of the Major Events Management Act, 35 of 2007. Since the promulgation of the Act three events have to date been identified as protected events, namely the 2011 Rugby World Cup, the FIFA U-17 Women's World Cup and the FIBA U-19 World Championship - see the report by Ironside "Ambush Marketing 
World Cup bid, national government departments provided a total of 17 guarantees to FIFA, which were subsequently (as per FIFA's requirements) consolidated in the 2010 FIFA World Cup South Africa Special Measures Act. ${ }^{21}$ These guarantees included, for present purposes, FIFA's ownership of media and marketing rights (Ministry of Communications; Ministry of Trade and Industry) and exploitation of marketing rights (Ministry of Trade and Industry). ${ }^{22}$ Following the establishment of the required legislative framework, the sports federations employ a veritable army of top-flight local lawyers to protect the rights of the event organizer (often by focusing their efforts on the "small fry" rather than the powerful non-sponsor corporations that may be skirting the bounds of legitimate marketing relating to events but who also have the deep pockets to enter into protracted and expensive litigation ${ }^{23}$ ).

Law Passes First Test" http://www.baldwins.com/ambush-marketing-law-passes-first-test (posted 2009-09-04). The Hon Trevor Mallard, New Zealand's Minister for the Rugby World Cup, was quoted as explaining the need for this legislation as follows:

"[T]he legislation will make New Zealand more attractive to major event organisers. Without it, New Zealand's success when bidding for similar events in the future, may be at risk. It is impossible to host major events these days without enormous financial contributions from large sponsors. These companies will not provide sponsorship dollars if others are allowed to manipulate public perceptions by falsely suggesting a link with these events."

From the undated (last updated 2009-09-16) report entitled "Proposed Ambush Marketing Bill Explained" http://www.med.govt.nz/templates/MultipageDocumentTOC41944.aspx. Kelbrick 2008 41(1) CILSA 38-39 refers to the criticism voiced by the New Zealand Law Society in response to the promulgation of this very extensive Act. The Law Society recognized that the justification for the Act was that some major international events could not be hosted unless such legislation existed, and suggested (which suggestion was not accepted) that an event should only be declared a protected event in terms of the Act if the relevant Minister is satisfied that this is necessary in order to secure hosting rights in respect of the specific event - from the New Zealand Law Society Submission on the Major Events Management Bill (see Kelbrick 2008 41(1) CILSA 39 fn 74).

In respect of the position in Australia, Curthoys and Kendall "Ambush Marketing and the Sydney 2000 Games (Indicia and Images) Protection Act: A Retrospective" June 2001 8(2) Murdoch University Electronic Journal of Law (par 43) observe the following in showing that the relevant legislative amendments prior to the Sydney 2000 Olympics were, primarily, in order to serve the commercial interests of event organizers and their sponsors:

"The [Sydney 2000 Games (Indicia and Images) Protection Act] itself is a comment on the power of the advertising dollar associated with the Olympic symbol and the Sydney 2000 Games - this intersection being made explicit in sub-section 3 of the Act which provides:

(1) The objects of this Act are:- (a) to protect, and to further, the position of Australia as a participant in, and a supporter of, the World Olympic and Para-Olympic movements; and (b) to the extent that it is within the power of the Parliament to assist in protecting the relations and ensuring the performance of the obligations of the Sydney 2000 Games bodies with and to the World Olympic and Para-Olympic movements, in relation to the holding of the Sydney 2000 Games. (2) These objects are to be achieved by facilitating the raising of licensing revenue in relation to the Sydney 2000 Games through the regulation of the use for commercial purposes of the indicia and images associated with the Games."

21 Act 12 of 2006.

22 For more on the FIFA 2010 bid guarantees, see Davies "Managing the Alchemy of the 2010 Football World Cup" in Pillay, Tomlinson and Bass (eds) Development and Dreams: The Urban Legacy of the 2010 Football World Cup (2009) 38-40.

23 Kelbrick 200841 (1) CILSA 2445 observes that FIFA's tactics are to threaten litigation in respect of every reference to its events, and that the organization "singles out smaller 
In this way, members of the public and entrepreneurs in the host nation are effectively deprived of most opportunities to benefit financially from the hype and excitement around such events - ironically, while these same persons are often by means of their tax dollars assisting to foot the bill for the vastly expensive infrastructure, stadium construction, transport etcetera, expenses that are necessitated by bid guarantees. The restrictions are also not only financial; issues such as "spring-cleaning" by event organizers through the forced removal of the homeless from the precincts of event venues, ${ }^{24}$ severe restrictions on the informal economic activities sector ${ }^{25}$ and often extensive restrictions on freedom of expression and of the media (for example, through extremely restrictive accreditation requirements) are, sadly, nothing new (also not in respect of the 2010 football World Cup event).

While it is by no means the intention here to deny the existence and value of the very real commercial interests and expense that are at stake in staging some of the greatest entertainment spectacles on earth, it will be submitted that the apparent and all-pervasive trend to seek to, at least ostensibly, protect such interests at all costs and by trumping all other considerations and interests - including, especially, the public interest in the hosting of major events - needs to be considered much more critically. Specifically, it will be contended here that the apparently sacrosanct nature of such events and of the commercial interests of those hosting and sponsoring them should be more closely scrutinised, from a legal perspective. The fact that FIFA and other international sports governing bodies conduct "business as usual" in all the jurisdictions where they

concerns with few financial or legal resources to defend themselves", and the author quotes a statement by FIFA's legal counsel prior to the 2006 FIFA World Cup:

"Big companies know where the grey zones are because they are well-advised ... We don't touch the grey areas ... [M] any companies, especially the smaller firms, won't take risks with this."

Stopper as quoted by Carvajal in the International Herald Tribune 31 May 2006 - see Kelbrick 200841 (1) CILSA in the text to $\mathrm{fn} \mathrm{118.} \mathrm{It} \mathrm{is,} \mathrm{in} \mathrm{this} \mathrm{light,} \mathrm{interesting} \mathrm{to} \mathrm{note} \mathrm{the}$ litigation instituted by FIFA in South Africa in respect of alleged ambush marketing of the 2010 World Cup event by what can only be termed "small players" (as discussed in the forthcoming Part 3 of this article), and the fact that when FIFA encountered an alleged ambush by the South African subsidiary of electronics giant LG Electronics in respect of the 2006 World Cup in Germany, FIFA only followed the complaint procedure of the Advertising Standards Authority rather than to instigate litigation - see par 21 of Part 1 of this article.

24 See the report by Raquel Rolnik, United Nations Special Rapporteur on adequate housing, of March 2010, which calls on FIFA and the IOC (and host governments) to ensure that mega-events such as the football World Cup and the Olympic Games do not lead to the displacement of the poor, through forced evictions, criminalization of homeless persons and informal activities, and the dismantling of informal settlements - see the report entitled "Olympics and World Cup Soccer must take up Cause of Right to Housing - UN Expert" 9 March 2010 UN News Centre www.un.org (accessed 2010-03-20). It was reported on 7 April 2010 that the City of Cape Town's efforts to move the residents of informal settlements had caused controversy and were claimed to be aimed at removing an "eyesore" for tourists in the run-up to the World Cup. City officials denied that such efforts were aimed at city beautification for the event, and claimed that they were part of a longer-term strategy to provide permanent housing for such residents.

25 Compare the very extensive restrictions on informal street traders as contained in the various 2010 host city municipal by-laws, as referred to elsewhere in this article. 
operate, does not take away from the fact that Mr Blatter et al - if they want to conduct such business in South Africa - must respect and comply with the country's laws and its Constitution.

The paragraphs that follow will critically evaluate the legitimacy of robust protection of commercial interests to sporting events (and, specifically, antiambush marketing measures) and the commercial monopolies that this aims to maintain, in terms of intellectual property law, competition law and the South African Bill of Rights. The latter part of the forthcoming Part 3 of the article will examine current developments elsewhere, with a view to evaluate the worrying potential for even more robust monopolization of sports events in future.

\section{EVALUATING THE LEGITIMACY OF DEVELOP- MENTS IN THE COMMERCIALIZATION OF SPORTS EVENTS IN THE SOUTH AFRICAN CONTEXT}

\section{The role of intellectual property laws: Legal protection for the commercial monopolization of sports events considered in light of the rationale behind IP rights}

This article will not contain detailed discussion of the use of intellectual property rights to exploit a sporting event commercially, or the various forms of intellectual property protections (for example, trademarks, copyright or registered designs) that are available to event organizers in order to protect against ambush marketing, or of the ins-and-outs of such litigation. The reader is referred to more specialized texts in this regard. ${ }^{26}$ This paragraph will evaluate the legitimacy of commercial monopolization of events on a more fundamental level, against the backdrop of the traditional notions and considerations that underlie intellectual property law. It will be my objective to evaluate to what extent the exclusive sponsorship and other commercial arrangements around major events, as well as the use of intellectual property rights in order to maintain such arrangements, are consonant with the traditional notions that underpin IP law and what it protects. This is especially poignant in light of developments in the last decade whereby specific legislation has been passed in a number of jurisdictions in order to provide special protection to major sports events and their associated intellectual property. Other authors have in recent years bemoaned the frequently apparent excesses in the enforcement of intellectual property laws primarily by large corporations, and the ways in which such laws (apparently contrary to notions and philosophies that have traditionally been accepted as underpinning (but also limiting) the protection of IP) have increasingly been

26 See, eg, Johnson Ambush Marketing: A Practical Guide to Protecting the Brand of a Sporting Event (2008) Chapters 2 and 3; Scaria Chapter 3; see also Kelbrick 2008 41(1) CILSA 24-48; Lewis and Taylor Sport: Law and Practice (reprint 2007) Chapter D1 (especially D1.36-D1.132); and Gardiner et al Chapters 10 and 11. 
used to monopolize aspects of popular culture and to promote narrow commercial interests over the public good. ${ }^{27}$ In this light it is interesting to note how IP laws have in the past few years increasingly been expanded upon to protect and maintain commercial monopolies in major sporting events.

Phillip Johnson has examined the apparent trend in such legislative measures against ambush marketing to more and more frequently provide what the author calls "IP +" protection for events. ${ }^{28}$ These "IP+" rights (which the author also refers to as quasi-intellectual property rights) refer to "association rights" 29 to events, and have been developed by certain legislatures since 2000. Johnson grants South Africa the (dubious?) distinction of being the first country to take the "bold step" of creating a protectable association right to a major event (that is, by prohibiting any association to be made with such event if unauthorised), by means of the amendment to section 9 of the Trade Practices Act, 1976, ${ }^{30}$ which Johnson calls "clearly ... a turning point in the prevention of ambush marketing" ${ }^{31}$

Following on this legislation, other jurisdictions have also proceeded to pass legislation to protect association rights to a number of events, by means of event-specific legislation (for example, in respect of the 2006 Melbourne Commonwealth Games, the EURO 2004 football tournament in Portugal, the 2006 Turin Winter Olympics in Italy, the 2010 Vancouver Winter Olympics and the future 2012 London Olympic Games), or by means of "umbrella" legislation (for example, New Zealand's much-maligned Major Events Management Act of 2007).

A provision such as section 9 of the South African Trade Practices Act ${ }^{32}$ to an extent blurs the line between the protection of intellectual property related

27 See, eg, Bollier Brand Name Bullies: The Quest to Own and Control Culture (2005); Lessig Free Culture: The Nature and Future of Creativity Penguin Books (2004); and Vaidhyanathan (2003).

28 Johnson "Look Out! It's an Ambush" 2008 2(3) International Sports Law Review 24-29.

29 Compare the "London 2012 Olympics Association Right" (discussed in the text below) created in terms of the London Olympic Games and Paralympic Games Act, 2006, which the legal advisor to a number of 2012 Olympics sponsors has characterised as a new "IP right" - see Stone "The Olympic Games Cannot Survive Without Sponsors and those Sponsors Need Legal Protection" 16 January 2006 The Lawyer.

30 The Trade Practices Amendment Act 26 of 2001 inserted s 9(d) in the Trade Practices Act 76 of 1976, which provision prohibits a person from making, publishing or displaying false or misleading statements, communications or advertisements which suggest or imply a contractual or other connection with a sponsored event or the person sponsoring such event. See the discussion in par 226 of Part 1 of this article.

Johnson 2008 2(3) International Sports Law Review 26.

32 Act 76 of 1976 (as amended by Act 26 of 2001). For other legislative provisions that outlaw "association ambushes" in South Africa, see s 29 of the Consumer Protection Act 68 of 2008, which is found in Part E (which deals with consumers' "right to fair and responsible marketing") and contains provisions regarding the marketing of goods or services. This section also prohibits ambush marketing by association with an event, and provides as follows:

"S29. A producer, importer, distributor, retailer or service provider must not market any goods or services -

(a) in a manner that is reasonably likely to imply a false or misleading representation concerning those goods or services ...; or 
to an event (for example, a FIFA trademark) and the common law "passing off" action, by constituting a legislative prohibition on deceiving or misleading the public regarding association with an event. It is "IP+" (that is, something more than IP) protection because liability in terms of such provision does not require any IP infringement (that is, there need not be any trademark, copyrighted work or registered design at issue; what is prohibited is creating confusion regarding an association, howsoever caused), and also because this type of provision that deals with an association with an event is often aimed at protecting something more than the traditionally recognized intellectual property of events organizers (for example, by claiming protection against the use of generic terms which would/do not qualify for IP protection in terms of originality and distinctiveness requirements). ${ }^{33}$ Such provisions have been enacted in different jurisdictions, ostensibly, as a result of a realization that existing legal protection in terms of the common law (for example, unlawful competition) or more general legislation (for example, deceptive trade practices legislation and IP statutes) does not provide satisfactory protection against the often novel and creative efforts of "ambushers". ${ }^{34}$

Mouritz ${ }^{35}$ examines the (then in Bill form) legislative protection against ambush marketing that was instituted for the 2010 Vancouver Winter Olympic Games, namely the Olympic and Paralympic Marks $\mathrm{Act}^{36}$ (hereinafter "the Vancouver Act"). This legislation is described as sui generis legislation aimed, primarily, at addressing the practical problems in combating ambush marketing surrounding the event (especially the time

(b) in a manner that is misleading, fraudulent or deceptive in any way, including in respect of ... the sponsoring of any event."

S 41 of the Act (dealing with "False, misleading or deceptive representations") contains the following:

"S 41(3).... [I]t is a false, misleading or deceptive representation to falsely state or imply, or fail to correct an apparent misapprehension on the part of a consumer to the effect, that -

(a) the supplier of any goods or services has any particular status, affiliation, connection, sponsorship or approval that they do not have."

33 See Mouritz "Challenging the Legal Enforceability of the Vancouver 2010 Olympic Games' Anti-ambush Marketing Provisions" 2008 1(16) Sport and the Law Journal 10-19 (see discussion in the text below).

34 Compare the discussion on the event-specific legislation that was prepared for the Sydney 2000 Olympic Games in Curthoys and Kendall June 2001 8(2) Murdoch University Electronic Journal of Law; and see also Frontier Economics Ambush Marketing Legislation Review (Prepared for IP Australia and the Department of Communications, Information Technology and the Arts) October 2007 17:

"[M]any legally-savvy companies are unlikely to be ... explicit in their ambush marketing tactics. Much concern about ambush marketing instead relates to far more subtle practices for which: (1) the application of existing law is uncertain or highly factdependent; or (2) there is no contravention of any law at all. The breadth of conduct that falls within this category demonstrates the creativity of marketers in finding ways to leverage off an event, either without infringing any law, or where legal uncertainty (combined with the time and cost of litigation) dissuades any enforcement action by 35 Ibid. the event organiser."

36 Bill C-47; the Bill received Royal Assent on 22 June 2007, and entered into force on 17 December 2007. 
factor; the author points out that an objective of the legislation was to provide timely and sufficient relief against ambush marketing by means of preventive injunctions). However, the author is of the view that "the Canadian Legislator, undoubtedly with all the best intentions in mind, seems to have gone overboard in some of its protective endeavours". ${ }^{37}$ The gist of Mouritz's criticism of the Vancouver Act relates to the Act's apparent failure to provide exemptions for liability for the use of the protected trademarks (and generic terms); notably, it appears that the exemption of liability for non-commercial use is especially narrow and, in the author's view, problematic and nonsensical.

For present purposes, however, I would like to focus on one specific aspect of the Vancouver Act, namely its apparent inclusion of non-IP protected matter. The Vancouver Act contains provisions regarding the protection of specific Olympic and Paralympic trademarks (as well as marks specific to the 2010 Vancouver event) ${ }^{38}$ and, more problematically, certain "generic Olympic terms". ${ }^{39}$ Mouritz points out that these last, especially, are rather problematic:

"[T]he generic terms listed in Schedule 3 [of the Bill] (the "Generic Olympic Terms") lack any ... distinctive character and are therefore not regarded as intellectual property rights. For this reason these generic terms do not have statutory legal protection and remedies similar to intellectual property rights. None the less the Bill has prohibited the use of such generic terms as 'Gold', 'Winter', 'Vancouver', '21 ${ }^{\text {st' }}$ and 'Sponsor'. These terms do not just lack any distinctive character, but are in fact common everyday expressions. In ordinary life and under normal circumstances, one cannot forbid individuals and companies the use of such common expressions. The fear of ambush marketing at Olympic Games has sparked a certain creativity to try and limit the use of these generic terms where it is used in - mostly commercial conjunction with the Olympics."

This Act provides a clear example of event-specific legislation being passed in order to provide more protection than would normally be available to event organizers or sponsors in terms of, in this case, intellectual property laws. Where the net is cast wider than normal in such manner, it becomes especially important to consider the exceptions to liability for contravention of such unusual prohibitions and restrictions (which, as mentioned, Mouritz has argued are largely deficient in respect of this Canadian legislation).

37 Mouritz 2008 1(16) Sport and the Law Journal 10.

38 These are covered by $\mathrm{s} 3$ of the Act, which provides as follows:

"No person shall adopt or use, in connection with a business, as a trademark or otherwise, an Olympic Trademark, or a translation thereof, or a mark that so nearly resembles an Olympic Trademark as to be likely to be mistaken for it."

39 This last in Schedule 3 of the Act. Use of these terms is covered in s 4 of the Act, which provides as follows:

"No person shall, in association with an Olympic Trademark or other mark, promote or otherwise direct public attention to their business, wares or services in a manner that misleads or is likely to mislead the public into believing that (a) the person's business, wares or services are approved, authorized or endorsed by VANOC [the local organizing committee] or any other Olympic body or, (b) there is a business association between the person's business and the Olympic Games, the Paralympic Games, VANOC or any other Olympic body." 
Johnson ${ }^{40}$ describes the "London Olympics association right", created by the London Olympic Games and Paralympic Games Act 2006 (hereinafter "the London Act"), as follows:

"The London Olympics association right is a sui generis right which was created to prevent people using innovative ways of making an association with the [London 2012] Games without the consent of the Organising Committee. It applies to any activity which takes place between 30 March 2006 and 31 December 2012. The London Olympics association right is an exclusive right which is actionable by the London Organising Committee. The right is to use any representation (of any kind) in a manner likely to suggest to the public that there is an association between the London Olympics [and Paralympics] and goods or services, or a person who provides goods or services ... The representation can be of any kind and so it would include verbal representations ... The association created by that representation need not be intentional ... There is no requirement that the association is misleading and so it does not matter that consumers are not confused. Accordingly, the representation must objectively create the association.'

In light of the broad scope of what appears to be outlawed by this association right, Johnson considers whether the use of a disclaimer might prevent infringement:

"It was clearly the intention of the legislator to give a broad protection against association and it would seem somewhat perverse if this could be circumvented by the inclusion of a disclaimer. This is particularly the case as there is no requirement as to confusion and so any reader will be making the association and then, at best, subsequently discounting it. This being the case, it is suggested that no disclaimer would be effective."

The London Act makes use of certain specified combinations of words (as contained in Schedule 4 to the Act) as indicators that a court may take into account in determining whether the association right has been infringed. Interestingly, when considered in light of the Vancouver Act as discussed above, these are also mostly generic terms that do not enjoy intellectual property protection: They include the words "games", "gold", "silver", "bronze", "London", "medals", "sponsor" and "Summer". As Johnson points out, the following two phrases would likely constitute specified combinations in terms of the Act which could (strictly read) lead to a finding of infringement:

$$
\begin{aligned}
& \text { "Come to London to see the Games" } \\
& \text { "Sponsor of the } 2012 \text { FA Cup"42 }
\end{aligned}
$$

Infringement of the London Olympics association right requires the use of a representation (which causes an association) in the course of trade ${ }^{43}$

\footnotetext{
Johnson 129-130.

41 Mouritz 2008 1(16) Sport and the Law Journal 1012 observes that the Vancouver Act, in its s 4 (see fn 39 above) appears to have created a similar association right to the London Olympics association right.

42 Johnson 131-132. Johnson does, however, point out that these two phrases would not likely be found to offend the association right and that a court is not obliged to take the specified combinations into account.
} 
within the United Kingdom, and without the consent of the London Organizing Committee. ${ }^{44}$ Of the specific exceptions to infringement, ${ }^{45}$ the author shall mention the following three:

- Registered trademarks:

It is not an infringement of the association right to use a trademark in relation to goods or services for which it is registered, and an application to register a mark that includes a representation that would infringe the association right is not a basis for the refusal of a registration on absolute grounds. The London Organizing Committee must therefore monitor trademark applications and oppose registrations that may infringe the association right. ${ }^{46}$

- Descriptive use:

The London Act exempts from liability for infringement the use of a mark for descriptive purposes, provided such use is in accordance with honest practices in industrial or commercial matters. ${ }^{47}$

- Prior rights:

The association right does not preclude the exercising of prior rights to, for example, symbols that a person may have had prior to the introduction of the association right. ${ }^{48}$

As will be shown later, the South African legislation does not contain similar exceptions to liability.

New Zealand enacted its controversial Major Events Management Act (or "MEMA") ${ }^{49}$ in 2007, in order to comply with the requirements of international sports federations (specifically the International Rugby Board) to, inter alia, establish a satisfactory legal framework for the combating of ambush marketing. Section 7 of MEMA provides for the declaration of an event as a major event, and section 8 for the declaration of major event emblems or words that are protected..$^{50}$ Section 10 of MEMA prohibits the representation of association with protected major events:

43 Contrast the apparent lack of non-commercial use exceptions in the Vancouver Act as discussed by Mouritz 2008 1(16) Sport and the Law Journal 10-19.

44 Johnson 131

45 Johnson 135-136.

46 The London Act Schedule 4 par 6.

47 The London Act Schedule 4 par 7.

48 The London Act Schedule 4 par 8 and 10.

49 Public Act 35 of 2007 (date of assent 28 August 2007).

50 S 8 provides as follows:

"8(1) The Governor-General may, by Order in Council made on the recommendation of the Economic Development Minister, declare any or all of the following:

(a) an emblem to be a major event emblem;

(b) a word, words if combined with other words, or a combination of words to be a major event word or major event words.

(2) The Economic Development Minister may only make a recommendation after consultation with -

(a) the Commerce Minister; and

(b) the major event organiser; and 
“(1) No person may, during a major event's protection period, make any representation in a way likely to suggest to a reasonable person that there is an association between the major event and -

(a) goods or services; or

(b) a brand of goods or services; or

(c) a person who provides goods or services.

(2) In subsection (1), a person who makes a representation includes a person who -

(a) pays for, commissions, or authorises the representation; or

(b) receives consideration for the placement or the location of the representation."

Section 11 of MEMA provides for certain presumptions regarding the representation of an association and also provides that a disclaimer will not avoid liability for contravention of section $10 .^{51}$ Section $12(1)(d)$ of the Act provides for a non-commercial use exemption to liability. ${ }^{52}$ It is an offence for a person to breach section 10 of the Act knowingly, and on conviction such person is liable to a fine not exceeding NZD $150000 .^{53}$

(c) persons the Minister considers are likely to be substantially affected by the recommendation.

(3) Before making a recommendation, the Economic Development Minister must take into account the extent to which, in relation to the major event, emblems and words require protection in order to -

(a) obtain maximum benefits for New Zealanders;

(b) prevent unauthorised commercial exploitation at the expense of either a major event organiser or a major event sponsor."

51 S 11 provides as follows:

"S11(1) The court may presume that a representation is in breach of section 10 if it includes any of the following:

(a) a major event emblem; or

(b) a major event word or major event words; or

(c) a representation that so closely resembles a major event emblem, a major event word, or major event words as to be likely to deceive or confuse a reasonable person.

(2) Subsection (1) applies even if the representation is qualified by words like 'unauthorised' or 'unofficial', or other words that are intended to defeat the purpose of section 10."

52 This section provides as follows:

"[Sections 10 and 11 do not apply if] in accordance with honest practices in industrial or commercial matters, the representation -

(i) is necessary to indicate the intended purpose of goods or services; or

(ii) is made by an existing organisation continuing to carry out its ordinary activities; or

(iii) is for the purposes of reporting news, information, criticism, or a review (including promoting that news, information, criticism, or review) in a newspaper or magazine, or by means of television, radio, film, the Internet, or other means of reporting; or

(iv) in the case of a word or emblem (provided that the word or emblem is not being used in combination with other words or emblems with the intention of suggesting an association that breaches section 10), comprises the whole or part of -

(A) the proper name of any town or road or other place in New Zealand; or

(B) the legal or trade name (not being used for the purpose of defeating the intention of this subpart) of the person making the representation; or

53 MEMA s 13

(C) an existing registered trademark." 
MEMA specifically deals with ambush marketing by intrusion, ${ }^{54}$ but it is interesting to note that such protections as are provided all deal with clean zones, clean transport routes and clean periods surrounding event venues and dates (and with restrictions on advertising within such zones and for such periods). MEMA does not contain any provision comparable to the wide anti-intrusion ambush provisions of section 15A of South Africa's Merchandise Marks Act (or "MMA", as it will be referred to in what follows).

Similar to some of the legislative provisions from other jurisdictions as mentioned above, we see that the protection afforded by means of section 15 of the MMA in South Africa also appears to extend, significantly, beyond what intellectual property law would normally protect. In fact, it appears that section $15 \mathrm{~A}$ goes much further than the legislation from other jurisdictions referred to above.

We have seen that legislation such as the Vancouver Act and the London Act make use of generic terms that are not IP-protected. In the Vancouver Act, the use of such terms is prohibited in respect of the "association right" contained in section 4 of that Act; in the London Act such generic terms may form specified combinations that a court may take into account in determining whether an infringement of the association right is present. The point, however, is that such generic terms are not terms that warrant

54 In subpart 3 of Part 2 of the Act.

55 Act 17 of 1941 (as amended by Act 61 of 2002) - see par 226 in Part 1 of this article. S 15A provides as follows:

"S15A Abuse of trademark in relation to event:

(1)(a) The Minister may, after investigation and proper consultation and subject to such conditions as may be appropriate in the circumstances, by notice in the Gazette designate an event as a protected event and in that notice stipulate the date -

(i) with effect from which the protection commences; and

(ii) on which the protection ends, which date may not be later than one month after the completion or termination of the event.

(b) The Minister may not designate an event as a protected event unless the staging of the event is in the public interest and the Minister is satisfied that the organisers have created sufficient opportunities for small businesses and in particular those of the previously disadvantaged communities.

(2) For the period during which an event is protected, no person may use a trademark in relation to such event in a manner which is calculated to achieve publicity for that trademark and thereby to derive special promotional benefit from the event, without the prior authority of the organiser of such event.

(3) For the purposes of subsection (2), the use of a trademark includes -

(a) any visual representation of the trademark upon or in relation to goods or in relation to the rendering of services;

(b) any audible reproduction of the trademark in relation to goods or the rendering of services; or

(c) the use of the trademark in promotional activities, which in any way, directly or indirectly, is intended to be brought into association with or to allude to an event.

(4) Any person who contravenes subsection (2) shall be guilty of an offence.

(5) For the purposes of this section 'trademark' includes a mark." 
intellectual property protection - they are, for example, not sufficiently "original" for purposes of copyright, and not sufficiently distinctive for purposes of trademark registration. Section 15A(2) of the Merchandise Marks Act, which deals with the "abuse" of a trademark relating to a protected event in terms of the Act, provides that during the period of protection of such event "no person may use a trademark in relation to such event in a manner which is calculated to achieve publicity for that trademark and thereby to derive special promotional benefit from the event, without the prior authority of the organizer of such event". This provision prohibits the use by a trader of his or her own registered marks, even in circumstances that would not be objectionable or actionable in terms of the common law or IP statutes. For example, in terms of the relevant trademark protection:

- Section 15A(2) does not limit its prohibition to the use of an identical mark to the mark(s) of an event organizer or official sponsor; ${ }^{56}$

- the section does not limit its prohibition to trademark use that is "likely to deceive or cause confusion" in respect of the marks of an event organizer or official sponsor,; ${ }^{57}$ and

- the section does not qualify liability in terms of the prohibition to use of a mark that is "likely to take unfair advantage of, or be detrimental to the distinctive character or repute of" a well-known mark. ${ }^{58}$

Also, the section does not qualify unlawful use of a mark in respect of the traditional requirements for liability for copyright infringement, that is, reproduction in material form of a substantial part of an original work. ${ }^{59}$

In light of what was said above regarding the protection of generic terms in other jurisdictions, it should also be noted that FIFA demanded similarly wide protection in respect of the 2010 World Cup. As was argued by the respondent in the FIFA v Metcash ${ }^{60}$ matter:

"In addition to applying to the Minister to designate the FIFA World Cup 2010 as a protected event, [FIFA] sought a blanket prohibition in terms of section 15(1)(b) of the Merchandise Marks Act on 'the use of certain words and emblems in connection with any trade, business, profession, occupation or event or in connection with the trademark, mark or trade description applied to goods other than the use thereof by FIFA or its mandatories'... A consideration of FIFA's application in this regard shows that it sought an outright prohibition of any use of SOUTH AFRICA 2010 or indeed of the depiction of a football for any purpose and in any context other than use by the applicant or its mandatories but, interestingly, did not seek a prohibition on the use of the South African flag. It is precisely this type of blanket prohibition that the applicant is now seeking to enforce through these proceedings notwithstanding the fact that the Minister refused to grant such a prohibition and instead restricted the terms of the prohibition so as to exclude the SOUTH

\footnotetext{
In respect of the infringement provisions of the Trade Marks Act 194 of 1993, see s 34(1)(a). Ss $34(1)$ (a) and 34(1)(b).

S 34(1)(c).

See the Copyright Act 98 of 1978.

60 [2009] ZAGPPHC 123 - see the discussion in the forthcoming Part 3 of this article.
} 
AFRICA 2010 emblem, the picture of a football and the word marks SOUTH AFRICA 2010 and SA 2010."

This led the respondents in that matter to argue the following:

"[FIFA] is attempting to prevent any use without its permission of signs or symbols which might, however remotely or obscurely possibly have some reference to the FIFA 2010 soccer world cup. In these proceedings the applicant attempts to achieve a complete monopoly on the use of any reference to SOUTH AFRICA 2010, or variations of such reference, on any products in any context whatsoever, despite having sought and failed to secure such a blanket prohibition in terms of legislation.

Section $15 \mathrm{~A}(2)$ of the MMA also clearly provides more rigid protection than is found in, for example, the London Act. When one considers the exceptions to liability in respect of the London association right as mentioned in the text above, it is clear that these would not be available to a defendant in a claim of contravention of section $15 \mathrm{~A}(2)$ (which, in fact, prohibits the use of a trader's own trademark). The restriction contained in section $15 \mathrm{~A}(2)$ is much wider and more open-ended than anti-ambushing protection provided elsewhere. For example, it is doubtful that non-commercial use exemptions would apply in respect of this provision, as the wording of the section does not require commercial use. In respect of non-commercial use, one could also compare this provision to that found in the Australian Olympic Insignia Protection Act, 1987 (or "OIP Act"):

The OIP Act was enacted to regulate the use of certain symbols, devices and expressions related to the Olympic movement in order to facilitate the commercial application of these designs by the national Olympic committee to realize a substantial proportion of the funds needed to ensure Australia's representation at the Olympic Games. The Act makes provision for certain protected expressions, including listed words and phrases, and provides the exclusive right to use or license such protected expressions to the Australian Olympic Committee (or AOC), by means of a prohibition on third parties to use such expressions for "commercial purposes" (subject to certain exemptions such as media reporting and the activities of athletes and sports organizations). ${ }^{63}$ A 2001 amendment to the OIP Act added a Chapter 3, which aims to facilitate licensing by regulating the commercial use of certain Olympic-related expressions. Section 36(1) of this chapter provides that a person, other than the AOC or a "licensed user" acting in accordance with their licence, may not use a "protected Olympic expression ${ }^{64}$ for commercial purposes". Section 30 of the OIP Act provides that use of a protected expression for commercial purposes includes a situation where a person

61 Federation Internationale de Football Association (FIFA) v Metcash Trading Africa (Pty) Ltd [2009] ZAGPPHC 123 - Respondent's Heads of Argument par 33-34.

62 Federation Internationale de Football Association (FIFA) v Metcash Trading Africa (Pty) Ltd supra - Respondent's Heads of Argument par 7-8.

63 From the report by Frontier Economics (see fn 34 above) 24.

64 These protected expressions are defined in s 24 of the Act as the words "Olympic", "Olympics", "Olympic Games", "Olympiad", "Olympiads", and any other expression "so closely resembling" any of those terms "as to be likely to be mistaken, by a reasonable person, for such a protected Olympic expression". 
"applies" a protected Olympic expression to their own goods or services; either for "advertising or promotional purposes" or in circumstances "likely to enhance the demand for goods or services"; and where such application would suggest to a reasonable person that the first person sponsors, sponsored, or is or was the provider of "sponsorship-like support" for the $\mathrm{AOC}$, the International Olympic Committee, organizing committee, Olympic games, team or athlete. Case law considering the meaning of "commercial purposes" (under the OIP Act and Australia's Sydney 2000 Games (Indicia and Images) Protection Act) suggests that "a precise rather than general association must be proved for support to constitute 'sponsorship' or [to be] 'sponsorship-like"'; the allegation of some "vague, undefined connection" is insufficient. $^{65}$

While the provisions of the OIP Act are reminiscent of section 9 (as amended) of the South African Trade Practices Act as well as section 29 of the Consumer Protection Act, 2008, it should be clear to the reader that section 15A(2) of the Merchandise Marks Act goes far beyond the type of restriction contained in the above Australian legislation. The MMA does not appear to include any non-commercial use exemption, and the use of a trademark within the wording of this section (that is, when calculated to achieve publicity for such mark and thereby deriving special promotional benefit from a protected event) also does not appear to refer specifically to commercial use only. It is submitted that a trademark can be used in this way in circumstances that may not necessarily be for a commercial purpose. ${ }^{66}$ When one considers, furthermore, that legislation such as that in Australia and the London Act is still aimed at prohibiting an "association" with the relevant protected event(s) (compare also the wording of section 30 of the OIP Act above), section 15A(2) of the MMA clearly goes beyond this (and thus catches "intrusion ambushes" in its net). Use of a trademark "in relation to an event", even where such use only relates to alluding to an event, is restricted. This last, in this observer's opinion, illustrates not only the wide ambit of this provision but also the apparent irrationality of its prohibition. The fact that section $15 \mathrm{~A}(2)$ does not require deception or confusion of the public or a representation of association with an event would make the use of a notice disclaiming such an association irrelevant for purposes of determining contravention of the provision. Accordingly, if a trader in using its trademark in an advertisement or even a public service notice (for example, a brochure or newspaper insert providing information on expected traffic movement and volumes in a specified area during such protected event) merely refers to a protected event and also includes a clear

65 From the Frontier Economics report (see fn 34 above) 29, with reference to the cases of Australian Olympic Committee v Baxter \& Co Pty Ltd (1996) 36 IPR 621 (decided under the Sydney 2000 Games (Indicia and Images) Protection Act); and Australian Olympic Committee v ERI Bancaire Luxembourg SA (2006) 69 IPR 135 (decided under the OIP Act).

66 Compare the hypothetical example of a protest march by Cosatu or the World Wildlife Fund, in which trade unionists carry banners depicting Cosatu's mark along with a slogan "Stop FIFA 2010 - Viva street traders!" or environmentalists carry banners with the WWF mark and a slogan "Show FIFA 2010 the red card for its carbon emissions!" In this author's view both these instances might be considered to fall within the wide ambit of the restriction contained in s $15 \mathrm{~A}(2)$ of the Act. 
notice to the public that it is in no way associated with such event, such conduct could still constitute the "abuse of a trademark" and be a criminal offence subject to the substantial fines or imprisonment.

Finally, it should also be noted that the protection afforded to the 2010 FIFA World Cup is for a much longer period than appears to be the norm elsewhere. The Minister's powers in respect of section 15A were extended specifically for purposes of the FIFA World Cup 2010, by means of the 2010 FIFA World Cup South Africa Second Special Measures Act 12 of 2006, ${ }^{67}$ in terms of which the duration of protection for the event was extended from the one-month period provided for in section 15A(1)(a)(ii) to a period of six months following the end of the event. ${ }^{68}$ When compared to for example, the Major Events Management Act in New Zealand, which provides that the declaration of an event as protected may not extend for more than 30 days after the completion or termination of major event activities, ${ }^{69}$ it is clear that South Africa's anti-ambush marketing protection of the FIFA event is not only significantly more rigorous than is the case elsewhere, it also applies for a much longer period of time. South Africa's very extensive anti-ambushing protection as contained in the Merchandise Marks Act will be considered again where relevant in the rest of this article.

\section{The potential role of South African competition law}

The Competition Act 89 of 1998 (hereinafter "the Act") ${ }^{70}$ has the purpose to promote and maintain competition, and it provides for the control and elimination of restrictive horizontal and vertical trade practices, of abuse of dominance, and of harmful concentration of economic power. The Act applies to "all economic activity within, or having an effect within, the Republic", ${ }^{71}$ and it has been held that a claimant does not have to show that such economic activity has had an adverse effect. ${ }^{72}$ The various facets of the organization, operation and commercialization of sport are not excluded from the ambit of the Act, and it thus applies to sport as it does to other commercial activities (as far as sport constitutes an economic activity). ${ }^{73}$ The

67 In terms of $\mathrm{s} 2$ of this Act, which provides as follows:

"If the Minister of Trade and Industry declares the 2010 FIFA World Cup South Africa a protected event in terms of section 15A(1) of the Merchandise Marks Act, 1941 ... he or she may, notwithstanding section $15 \mathrm{~A}(1)$ (a)(ii) of that Act, stipulate by notice in the Gazette a date later than one month but not later than six months after the completion or termination of the final competition as the date on which the protection afforded by such a declaration ends."

68 The 2010 FIFA World Cup is scheduled to be played from 11 June to 11 July 2010.

69 MEMA s 9.

70 The 1998 Act (which came into effect on 1 September 1999) replaced the Maintenance and Promotion of Competition Act 96 of 1979, which had established an administrative body (the Competition Board) to investigate competition matters. The 1979 Act covered three areas or categories of conduct, namely acquisitions, restrictive practices and monopoly situations see Brassey Competition Law (2003) 74 et seq.

71 S 3(1) of the Act.

72 American Natural Soda Ash v Competition Commission of SA Supreme Court of Appeal Case No. SCA 554/03 (judgment delivered 13 May 2005).

73 Loubser in Basson and Loubser (eds) Sport and the Law in South Africa Chapter 8-46. 
Act does contain two important exemptions in respect of its application (which may serve to exclude a sports matter from the ambit of its purview). Collective bargaining in the employment context, within the meaning of the right to fair labour practices as contained in section 23 of the Constitution ${ }^{74}$ and in terms of the Labour Relations Act, ${ }^{75}$ is excluded from the application of the Act. ${ }^{76}$ The Act also does not apply to "concerted conduct designed to achieve a non-commercial socio-economic objective or similar purpose". ${ }^{77}$ Section $10(4)^{78}$ of the Act reflects recognition by the legislature of the social value of intellectual property rights ${ }^{79}$ and the need for the Competition Commission to be able to exempt certain prohibited practices from the application of the prohibited conduct contained in Chapter 2 of the Act. ${ }^{80}$

In the sporting context, various activities regarding the organization and commercialization of sport may come into conflict with the prohibited practices covered by the Act. ${ }^{81}$ These include, foremost, practices and policies regarding the restriction of movement of players through the provisions of employment contracts and regulations, merchandising arrangements and the collective selling of broadcasting rights. ${ }^{82}$ Other potential conflicts may also arise, regarding such diverse issues as common ownership of competing clubs in a league, player-agent regulations and ticketing arrangements for events. ${ }^{83}$

74 The Constitution of the Republic of South Africa, 1996.

75 Act 66 of 1995.

76 S 3(1)(b) of the Competition Act 89 of 1998.

77 S $3(1)(e)$.

78 S 10(4) provides that "[a] firm may apply to the Competition Commission to exempt from the provisions of this Chapter an agreement or practice, or category of agreements or practices, that relates to the exercise of intellectual property rights, including a right acquired or protected in terms of the Performers' Protection Act 11 of 1967, the Plant Breeders' Rights Act 15 of 1976, the Patents Act 57 of 1978, the Copyright Act 98 of 1978, the Trade Marks Act 194 of 1993, and the Designs Act 195 of 1993".

79 The tensions between competition laws and intellectual property law (which last is premised on the creation of "limited monopolies") are fundamental and not unique to any specific jurisdiction; see eg, Scaria 116.

80 See Brassey 316.

81 In the context of the subject of this article, it is relevant to consider the view expressed in Lewis and Taylor 192 (par A3.166):

"[I]n many contexts, the most important controlling factor on a sports governing body's activities is the competition rules. This is particularly the case ... where a sports governing body enters into commercial arrangements to exploit economically the rights in the sport, and some providers are chosen as commercial partners in preference to others."

The authors refer to two matters, Hospitality Group v Football Association (24 January 1996, unreported) and a matter relating to the Rugby World Cup 1999; in both these matters the competition law claims were unsuccessful.

$82 \mathrm{Eg}$, see discussion of UEFA's marketing of broadcasting rights for the Champions League competition, in Gardiner et al 391 et seq. See also the interesting paper by Falconieri, Palomino and Sakovics "Collective vs. Individual Sale of TV Rights in League Sports" August 2002 http://www.econ.ed.ac.uk/papers/Collective_vs_Individual_Sale_of_TV_Rights in League Sports.pdf; and the article by Findlay, Holohan and Oughton "A Game of Two Halves? The Business of Football" Football Governance Research Centre, Birkbeck, University of London http://www.football-research.org/gof2h/Gof2H-chap6.htm.

83 In respect of ticketing arrangements, compare the decision of the European Competition Commission in the France 1998 World Cup case regarding abuse of dominance in terms of 
It should also be borne in mind that the application of competition law in the sporting context must proceed with due regard for the special characteristics and exigencies of this form of activity. In the European Union the "sporting exception" to competition rules has often been invoked; namely that the practice of sport is subject to European Community law to the extent that it constitutes an economic activity. ${ }^{84}$ However, as has been observed, this principle is "easy to state but less easy to apply in practice", mainly due to the fact that many rules that are characterized as mere "rules of sporting conduct" have undeniable and often fairly direct economic effects. ${ }^{85}$ Conversely, one could argue that the peculiar characteristics of the organization of sport (and, particularly, the monopoly position and powers enjoyed by sports governing bodies in terms of the European model of governance) may tend to facilitate unlawful or unfair competitive practices. ${ }^{86}$ It is submitted that, in respect of considering whether sports-related conduct or practices fall foul of the provisions of the South African Competition Act, all the relevant circumstances of the specific context of the sport as well as the need to promote competition through sometimes prima facie restrictive practices in order to promote or maintain the viability of the sport, must all be considered with proper weighting of the interests of the various stakeholders. ${ }^{87}$ In the context of the present discussion, this requires specific consideration of the argument raised against ambush marketing and in justification of the various forms of protection against such activities by sports bodies and sponsors, namely that guarantees of exclusivity of sponsorship (and the protection thereof) are essential for the attraction of sponsors and thus for the viability of these very expensive to organize major events.

Article 82 of the EC Treaty - Case IV/36.888 1998 Football World Cup (see Gardiner et al 360-362).

84 Cf Walrave and Koch v Union Cycliste Internationale [1974] ECR 1405; Dona v Mantero [1976] 1333; and Bosman's case [1996] 1 CMLR 645; Deliege [2000] ECR I-2549. Eg, in the Dona case, the following was said in the context of eligibility rules based on athletes' nationality:

"[The European Union freedom of movement provisions] do not prevent the adoption of rules or of a practice of excluding foreign players from participation in certain matches for reasons which are not of an economic nature, which relate to the particular nature and context of such matches and are thus of sporting interest only, such as, for example, matches between national teams from different countries."

See, in respect of the justiciability of "rules of the game" and "ethical principles of sport" in respect of their economic consequences, Foster "Is There a Global Sports Law?" Spring 20032 2(1) Entertainment and Sports Law Journal 15 and 16.

A recent judgment on this issue (by the European Court of First Instance) in the appeal of David Meca-Medina and Igor Majcen $v$ Commission of the European Communities (Case C519/04 P; judgment delivered 18 July 2006) has seen a review of the earlier cases mentioned above, and a finding that "the mere fact that a rule is purely sporting in nature does not have the effect of removing from the scope of the Treaty the person engaging in the activity governed by that rule or the body which has laid it down" (par 27 of the judgment).

85 Lewis and Taylor 347-348.

86 See the discussion in the text below regarding abuse of dominance and the relevance of the governance structure employed in professional sports.

87 See also Gardiner et al 365-367.

88 For further discussion of this justification, see the discussion below. 
The application of the Competition Act in the sporting context has to date not been tested by the courts, and one would have to wait and see how these specific considerations in respect of sport will be applied when such opportunity arises. It is hoped, however, that the courts as well as the Competition Commission and Tribunal will, where applicable, show an insight and sensitivity into the special nature of sport, as the European Competition Commission has done in recent times.

In the context of the commercialization of major events, it is submitted that practices such as category exclusivity of sponsorships raise questions regarding the restricted practices in terms of the Competition Act, specifically the restricted horizontal practices and abuse of dominance. ${ }^{90}$

Restrictive horizontal practices are prohibited by section 4(1) of the Act, which provides as follows:

"An agreement between, or concerted practice by, firms, or a decision by an association of firms, is prohibited if -

(a) it is between parties in a horizontal relationship and it has the effect of substantially preventing or lessening competition in a market, unless a party to the agreement, concerted practice or decision can prove that any technological, efficiency or other pro-competitive gain resulting from it outweighs that effect; or

(b) it involves any of the following restrictive horizontal practices:

(i) directly or indirectly fixing a purchase or selling price or any other trading condition;

(ii) dividing markets by allocating customers, suppliers, territories, or specific types of goods or services; or

(iii) collusive tendering."

The object of the prohibition in section 4(1) is threefold, namely an agreement between firms, a concerted practice by firms or a decision by an association of firms. ${ }^{91}$ An "agreement" includes a contract, arrangement or understanding, whether or not it is legally enforceable. A "concerted practice" by firms means co-operative or co-ordinated conduct between firms, achieved through direct or indirect contact, that replaces their independent action, but which does not amount to an agreement. "Firms" are defined in the Act as including a person, partnership or trust, and clubs and other sports bodies would undoubtedly qualify as firms for purposes of the Act. ${ }^{92}$ It should also be noted that the meaning of "firm" is not limited to its common law meaning. The word "person" (in the above definition) includes

89 Gardiner et al 397.

90 As observed by Scaria 117:

"[S]ports have an intricate connection with contemporary economic and marketing strategies and nowadays it is almost considered as an economic activity by itself. The moment event organisers engage in economic activities, the competition authorities will receive the locus standi to oversee them to ensure fair competition and to protect the interests of consumers. As many provisions of the event-specific legislation against ambush marketing contain elements of imposed exclusivity, they have to pass through the tests laid down by competition laws to assure fair competition in the market."

91 See Brassey 129.

92 Loubser Chapters 8-46(1). 
any company or body of persons whether incorporated or unincorporated ${ }^{93}$, and the provision thus applies to companies. ${ }^{94} \mathrm{~A}$ "horizontal relationship" is defined as a relationship between competitors.

The exemption regarding the proof of technological efficiency or a procompetitive gain which outweighs the anti-competitive effect of an agreement or concerted practice is similar to the provisions of Article 81(3) of the EC Treaty.

Sections 4(2) to 4(4) of the Act contain a presumption of the existence of an agreement to engage in a restrictive horizontal practice between two or among more firms, if there is cross-shareholding between or among firms or where they have at least one director or substantial shareholder in common. ${ }^{95}$ As Loubser has pointed out, media companies often have substantial shareholding in competing sports bodies, and the presumption of contravention of section 4 may arise in instances where these bodies engage in conduct that might be viewed as a restrictive horizontal practice (for example, where they appear to divide geographical markets in respect of the employment of players, or enter into exclusive broadcasting agreements with media companies).

It is submitted that it is worth considering to what extent, if any, practices in the commercial ring-fencing of rights in respect of major sports events might constitute a restrictive horizontal practice in the meaning of section 4 of the Act. Scaria, ${ }^{96}$ in the context of anti-ambush marketing legislation and India's Competition Act of 2002, ${ }^{97}$ observes that the two main competition law issues that arise in respect of typical anti-ambush marketing provisions are those relating to restrictions on advertisements associating the marketer with an event, and provisions relating to restrictions on products and services in and near the event venue. ${ }^{98}$ It is submitted, however, that potential competition law issues in respect of the very interests that are sought to be protected by anti-ambush marketing legislation are more fundamental. For example, the practice of category exclusivity in terms of agreements $^{99}$ between sports bodies (for example, FIFA) and official

93 In terms of s 2 of the Interpretation Act 33 of 1957.

94 See Campbell 129 fn 1.

95 In terms of s 4(5) of the Act, the provisions of s 4(1) do not apply to an agreement between or a concerted practice engaged in by a company, its wholly owned subsidiary, a wholly owned subsidiary of that subsidiary or any combination of them, or between the constituent firms within a single economic entity similar in structure as a company and its wholly owned subsidiaries.

96 Scaria 117.

97 Which replaced the Indian Monopolies and Restrictive Trade Practices Act of 1969 as a result of the changes brought about in the Indian economy through economic liberalization in the 1990s - see Scaria 132 fn 40.

98 In respect of the position in terms of South African legislation, see the discussion in par 22 6 of Part 1 of this article.

99 Gardiner et al (447) mention the wide range of commercial rights and opportunities available to sports sponsors (specifically in relation to major events), which sports governing bodies offer on the basis of exclusivity between categories. These include title sponsorship, event sponsorship, broadcast sponsorship of events, team and individual athlete sponsorship, official designations (eg, official airline or official credit card), official supplierships (eg, in respect of sports equipment), franchise and display rights (eg, the 
sponsors might conceivably be viewed as an agreement or concerted practice between firms in a horizontal relationship ${ }^{100}$ which has the effect of substantially preventing or lessening competition in a market (namely the sponsorship market and any market associated with the marketing of goods or services by entrepreneurs in connection with the relevant event) in the meaning of section $4(1)(a)$; such practice may also constitute conduct that serves to divide markets by allocating customers, suppliers, territories, or specific types of goods or services in respect of the event (in the meaning of section $4(1)(b)(i i))$. Similarly, the practice of saturation sponsorship ${ }^{101}$ as a means of preventing ambush marketing in respect of an event in terms of such exclusive arrangements might open the conduct of the sponsors involved to scrutiny in terms of section 4 .

In fact, it is submitted that it is hard to imagine a more blatant example of the use of the significant power wielded by an absolute monopoly to coerce legal recognition and protection of a completely closed market, which would in other contexts immediately raise eyebrows amongst competition authorities.

In respect of evaluating the legitimacy of the exclusive sponsorship agreements - which have as its main components the licensing by the relevant event organizer of intellectual property related to the event for the exclusive use of the sponsor (for example, in a specific category, such as a supply agreement for the supply of beverages or motor vehicles) as well as the granting of rights to associate the sponsor's product or service with the event in advertisements - it should be borne in mind that the TRIPS agreement ${ }^{102}$ contains specific provisions regarding control of anticompetitive practices in contractual licences. ${ }^{103}$ Article 40.1 recognizes that "some licensing practices or conditions pertaining to intellectual property rights which restrain competition may have adverse effects on trade and may impede the transfer and dissemination of technology". Article 40.2, accordingly, provides as follows in respect of the competency of member states to combat such restrictive practices or contractual licences:

exclusive sale of a sponsor's soft drinks), official programme sponsorship, product and character merchandising (eg, team mascots), commemorative items, premiums and other promotional items, corporate hospitality and tickets and access to VIP areas. See also Lewis and Taylor par D5.17 et seq.

100 While the Act defines a horizontal relationship as one between competitors, it is submitted that a relevant sports organization and commercial entities active in the sponsorship market would qualify as being in a horizontal relationship vis a vis the consumer public. Alternatively, it is submitted that such practice of sponsorship exclusivity might constitute a restricted vertical practice in terms of $\mathrm{s} 5$ of the Act, which provides that a "restriction between parties in a vertical relationship is prohibited if it has the effect of substantially preventing or lessening competition in a market, unless a party to the agreement can prove that any technological, efficiency or other pro-competitive gain resulting from that agreement outweighs that effect". A "vertical relationship" is defined in the Act as the relationship between a firm and its suppliers, it customers or both.

101 See the discussion in par 222 of Part 1 of this article.

102 The Agreement on Trade-Related Aspects of Intellectual Property Rights, as administered by the World Trade Organization.

103 In Section 8: Article 40 of the Agreement. 
"Nothing in this Agreement shall prevent Members from specifying in their legislation licensing practices or conditions that may in particular cases constitute an abuse of intellectual property rights having an adverse effect on competition in the relevant market ... [A] Member may adopt, consistently with the other provisions of this Agreement, appropriate measures to prevent or control such practices, which may include for example exclusive grantback conditions, conditions preventing challenges to validity and coercive package licensing, in the light of the relevant laws and regulations of that Member."

It appears that little, if anything has been done by WTO members to prohibit anti-competitive practices in respect of the exclusive sponsorship arrangements around major sports events.

It is important to determine the relevant market for purposes of application of the prohibitions contained in the Competition Act. The relevant market is usually determined primarily in respect of the product or service market and the geographical market. ${ }^{104}$ The market in which sports bodies or participants operate may be local, regional, national or international, depending on the nature of the activity or restriction concerned. ${ }^{105}$ Accordingly, for example, competition policy in respect of sports broadcasting rights raises difficult questions in determining the relevant market for the sport concerned. ${ }^{106}$ As has been observed in respect of the prohibitive effect of the competition provisions contained in the EC Treaty (that is, Article $81^{107}$ ), it is necessary to show not simply that the rule or practice is restrictive but also that the rule or practice has an appreciable effect on a relevant market. Therefore, a key element in any competition law analysis is defining the relevant market: a broad definition of the relevant market may lead to the conclusion that the rule or practice under scrutiny has no appreciable impact on competition ${ }^{108}$ (similarly a broad definition of the relevant market may lead to a conclusion that the undertaking under scrutiny does not enjoy a dominant position in the market - Article 82 of the EC Treaty; section 8 of the Competition Act 89 of 1998 - discussed below). ${ }^{109}$ In casu there appears to be little difficulty in determining the relevant market to be the market for merchandise, goods and services marketed on the basis of the publicity value surrounding a major event (such as, for example, the

104 Loubser Chapter 8-46(1); and Beloff, Kerr and Demetriou Sports Law (1999) 6.43.

105 Ibid.

$106 \mathrm{Eg}$, whether there should be a distinction drawn between pay-television and nonsubscription television, whether there are separate markets for live and recorded sports, and what the relevant geographical market is in respect of sports broadcasting - see Loubser Chapter 8-46(3). In the report of the UK Competition Commissioner in the Vivendi/BSkyB merger (April 2000), the Commission was of the opinion that pay-TV and free-to-air TV can be regarded as separate markets. This view appears to have also been followed in other jurisdictions (eg, in Italy and Germany) - see Lewis and Taylor 400-401. For a recent competition law challenge in respect of sports broadcasting rights, see the Federal Court of Australia case on the pay tv industry in the 1990s and early 2000s, Seven Network Limited v News Limited [2009] FCAFC 166 (2 December 2009).

107 Article 81 prohibits "all agreements between undertakings, decisions by associations of undertakings and concerted practices which may affect trade between Member States and which have as their object or effect the prevention, restriction or distortion of competition within the common market ..."

108 Or of not "substantially preventing or lessening competition in a market", in the wording of s 4(1) of the Competition Act 89 of 1998 (as quoted above).

109 Lewis and Taylor 354; and see also Brassey 109-110. 
2010 FIFA World Cup South AfricaTM); it is also clear that exclusive sponsorship arrangements and restrictions on the use of reference to or association with an event by others would clearly have an appreciable effect on such market in terms of substantially lessening or preventing competition in such market.

It remains to consider whether the mentioned arrangements and practices (for example, exclusivity of sponsorship rights and saturation sponsorship practices) may be exempted from scrutiny in terms of the Act, for whatever reason. For example, and as was mentioned above, the Act does not apply to "concerted conduct designed to achieve a non-commercial socioeconomic objective or similar purpose". ${ }^{110}$ It is submitted, however, that notwithstanding the emphasis that has been placed on the expected socioeconomic benefits of an event such as the 2010 football World Cup, ${ }^{111}$ the relevant commercial arrangements and the modern nature of such major events (as huge entertainment spectacles that are organized for gain) would fail to clear the hurdle of a non-commercial objective in terms of the Act. In fact, one might go as far as saying that the relevant arrangements have as their express purpose the unashamed creation of a profit-seeking commercial monopoly.

Which brings one to consider the internal exception contained in section 4 of the Act, which exempts agreements or concerted practices where it can be proved that "any technological, efficiency or other pro-competitive gain resulting from it outweighs [the effect of substantially preventing or lessening competition in the market]". (It should be noted that this exemption does not apply to the restrictive horizontal practice contained in section 4(1)(b)(ii) of the act, which relates to "dividing markets by allocating customers, suppliers, territories, or specific types of goods or services"). This raises the argument so often advanced by sports governing bodies and their commercial partners in defending their efforts at combating ambush marketing and in protecting the exclusivity of commercial arrangements, namely that in the absence of exclusivity no sponsors would be willing to participate in the hosting of

S 3(1)(e).

111 In this regard it is interesting to consider also the following proviso as contained in $s$ $15 \mathrm{~A}(1)$ (b) of the Merchandise Marks Act (see the discussion in par 226 of Part 1 of this article), which provides as follows regarding the Minister of Trade and Industry's power to declare an event a "protected event" in terms of the Act (as was done in respect of the 2010 football World Cup):

"The Minister may not designate an event as a protected event unless the staging of the event is in the public interest and the Minister is satisfied that the organisers have created sufficient opportunities for small businesses and in particular for those of the previously disadvantaged communities (author's emphasis). In light of the restrictions placed on association with the event and the use of the publicity value of the event, as well as the frequent media reports of disgruntled traders and entrepreneurs who appear to have come up against a veritable brick wall in attempts to cash in on the marketing value of the event, it is doubtful to what extent, if any, serious consideration was given to the contents of this proviso by government in the process of instituting the legal protection of the Merchandise Marks Act to the World Cup. The author is not in possession of information regarding the extent to which this provision was complied with (or not) in the process of declaration of the 2010 FIFA World Cup South Africa ${ }^{\mathrm{TM}}$ as a protected event." 
events and it would become virtually impossible to organize such expensive showcases. Leaving aside, for now, the veracity or accuracy of this justification, ${ }^{112}$ let us consider whether such consideration would constitute an "efficiency or other pro-competitive gain" which outweighs the anticompetitive effects of the practices involved.

Again using the example of the football World Cup, it is this observer's view that there would be little merit in such argument serving to exempt potential anti-competitive behaviour as is under discussion here. Football as a sport will always have its "World Cup" or something akin to it, that is, a tournament symbolizing the pinnacle of global competition in which the best talents that different nations have to offer compete at the highest international level for the bragging rights of being world champions. The same goes for all other major organized sports. If a nuclear bomb were to hit Zurich tomorrow and FIFA were to pass out of existence, any successor to the organization which takes control of international football would eventually establish a world championship tournament for the sport. Surely the amount of money available to organize such a showcase has little potential impact on the existence of the event, aside from the scale upon which the event is offered. If one considers the fact that mega-event organizers consistently show a profit (as will be examined in the forthcoming Part 3 of this article), the fact that hosting such events in this day and age costs a lot of money (and accordingly does require sponsor and other support) does not justify the level of commercialization as experienced in recent years. In this observer's view the rationale for anti-competitive arrangements as mentioned above does not constitute an "efficiency" or "pro-competitive" gain in the wording of section 4 of the Act (and the technological-gain exemption clearly does not apply). For as long as sports governing bodies and their commercial partners are unable to prove unequivocally that less exclusive commercial rights arrangements or ambush marketing practices threaten the very existence of events (which some observers appear to dispute ${ }^{113}$ ), it is submitted that merely being able to show that "we can organize a bigger event if we have more money"114 does not qualify to exempt such (what this

112 Which will be examined more closely in Part 3 of this article.

113 Compare eg, Schmitz "'Ambush Marketing: The Off-field Competition at the Olympic Games" Spring 20053 Northwestern Journal of Technology \& Intellectual Property 203 see fn 3 above; and Curthoys and Kendall June 2001 8(2) Murdoch University Electronic Journal of Law (par 17) observe the following:

"[T]he organisers of major sporting events have all expressed concern that competition of this sort will diminish their ability to retain top paying sponsors, thus jeopardising their ability to fund these events. To some extent, recent events would seem to support their concerns, although it remains unclear if ambush marketing is in fact having as much of a negative impact on sponsor investment as critics would have us believe."

114 In this author's view, the following rather bald assertion is not particularly convincing without evidence to support it:

"Organising and conducting a soccer world cup tournament is said to be very expensive. According to [FIFA's deponent to its founding affidavit] it cost in excess of R 5 billion to stage the 2006 tournament which was held in Germany. To stage the tournament, [FIFA] is said to rely on: television rights which it grants to broadcasters; sponsorships by commercial enterprises, merchandising goods and services that have a connection in the course of trade with the tournament and licensing its sponsors and 
observer views as) blatantly anti-competitive behaviour from competition provisions as contained in section 4 of the Competition Act or in similar provisions found elsewhere (for example, Articles 81 and 82 of the EC Treaty). As Kelbrick has observed, it appears that sports governing bodies' stated justification for the need for anti-ambush marketing protection is almost always couched in the language of protecting licences for commercial reasons in order to maximize profits from the hosting of events. ${ }^{115}$ As will be mentioned below, it appears from FIFA's financial reports that a large chunk of the income derived from its sponsors and commercial partners in fact does not go towards covering the organizational costs of an event like the World Cup (in fact, much of the burden appears to be shifted to local organizing committees and their host governments). Which reiterates the need for scrutiny of the justification for anti-ambush marketing (especially in respect of "intrusion ambushes") legislation, as discussed below. If it can be shown that sponsorship revenue is not, primarily, needed for the staging of events, one could assume that the key purpose of the exclusive commercial arrangements is to generate profit for event organizers (governing bodies) and to provide monopoly protection of the publicity value of the events for the commercial partners. The fact that FIFA may promise such monopolies to their sponsors does not mean that the law must provide the tools to maintain such monopolies through the means of (what is hoped is shown in this article to be) often extremely invasive legislation.

It is submitted that one should also here not lose sight of the fact that, at least in terms of South African law, the conduct by an organization such as FIFA as far as it affects the interests of others (that is, non-sponsor business entities and entrepreneurs) is not based on the protection of a legally recognized right to the spectacle provided by an event; ${ }^{116}$ in fact, the protection of exclusive commercial arrangements with sponsors serves to protect purely contractual rights deriving from the relevant sponsorship agreements, which rights are in terms of South African law not enforceable against non-parties to such agreements. While the goodwill in such events enjoys protection in terms of the common law (for example, the relevant protection against passing off), it is less clear that the publicity value that is "piggy-backed" by intrusion ambushers is worthy of legal protection. In order to get around this problem and in as far as the prohibited conduct of third parties (the "ambush marketers") does not constitute unlawful competition or intellectual property rights infringement, such conduct is invariably regulated by means of often far-reaching legislation which host countries are required to pass as part of a quid pro quo for the right to host the event.

merchandisers who use its intellectual property. The licensees and sponsors expect protection and a measure of exclusivity when they pay the fees. It follows therefore, it is submitted by [FIFA], that no licensee or sponsor would want to be associated with the soccer world cup unless all who enjoy the benefits pay fees which usually comprise large sums of money."

From par 1 of the court's order in Federation Internationale de Football Association (FIFA) $v$ Metcash Trading Africa (Pty) Ltd [2009] ZAGPPHC 123 - see discussion in the forthcoming Part 3 of this article.

115 See Kelbrick 2008 41(1) CILSA 46-47.

116 See discussion elsewhere in this article in this regard. 
The Competition Act, in its Part $\mathrm{B},{ }^{117}$ also prohibits the abuse of dominance in a market, which has been explained succinctly as follows:

"A firm that dominates a market may not exploit its power in order to gain an anti-competitive advantage over its competitors, customers or suppliers. It may not charge its customers excessive prices, improperly discriminate between customers in the prices it quotes them or improperly dictate the way its suppliers, competitors or customers deal with others."

Sections 7, 8 and 9 of the Act deal with abuse of a dominant position. Section 7 deals with the circumstances in which a firm is deemed to be dominant in a market, section 8 determines the standards against which a dominant firm is judged to have abused its dominance, and section 9 prohibits price discrimination by a dominant firm. ${ }^{119}$

Sports governing bodies (and their "commercial arms" tasked with regulating the commercial aspects of a sport) will always be exposed to potential claims of abuse of dominance, especially in light of the monopolistic nature of such governing bodies in terms of the European system of sports governance which characterizes the governance of the three major South African professional sports. These bodies, and especially national governing bodies (and their commercial arms which control the professional competitions etcetera), can by their very nature and the nature of their authority in regulating most aspects of the sport at all levels of participation be characterized as monopoly regulators with inherent market dominance. ${ }^{120}$ Their very reason for being is the establishment of a monopoly of control of professional sport and exploitation of its commercial spin-offs, and to fulfil a regulatory function of maintaining monopolies of control also at national level. ${ }^{121}$ For example, in respect of the economic characteristics of professional team sports, it has been noted that the most valued product of a sports league is the world or national championship contest, which only a monopoly can supply. ${ }^{122}$ Accordingly, aspects of the conduct of such bodies are eminently open to scrutiny in terms of

\footnotetext{
Ss $6-9$ of the Act.

118 Brassey 180.

119 lbid.

120 See Foster "Can Sport be Regulated by Europe? An Analysis of Alternative Models" in Caiger and Gardiner (eds) Professional Sport in the EU (2001) 59.

121 As has been stated in respect of the establishment of FIFA:

"The main idea behind [the meeting in 1904 of the founding members of the organisation] was to create a body with legitimacy to arbitrate over conflicts among national football associations and later to assure the presence of one national association per country and the development of football across all member nations. This legitimacy came with time, when an ever-growing number of affiliations pleaded their affiliation to FIFA, and with the monopolistic characteristic that the body impressed at all levels of football governance: Only one association per country would be officially recognised as sovereign responsible for the control and the development of the sport within its boundaries."

Ducrey, Ferreira, Huerta and Marston "UEFA and Football Governance: A New Model" 2004 1-2 International Sports Law Journal 81.

122 See Neale "The Peculiar Economics of Professional Sport" 1964 Quarterly Journal of Economics 78, 1:1-14, as discussed in Downward and Dawson The Economics of Professional Team Sports Routledge (2000) 21.
} 
competition law. This was recently confirmed in respect of the application of Article 82 of the EC Treaty ${ }^{123}$ in the decision of the Grand Chamber of the ECJ in the case of Motosykletistiki Omospondia Ellados NPID (MOTOE) $v$ Elliniko Dimosio. ${ }^{124}$ It was held that the abuse of a dominant position by a sports regulatory body (in casu, in motorcycling) in respect of sanctioning new events is subject to the prohibition contained in Article 82. As one commentator has observed, the ECJ's view in this regard is not surprising, but in line with a long line of earlier decisions whose effect has been summarized as follows:

"Case law [of the ECJ] demonstrates the Court's consistent view that sport, in so far as it constitutes an economic activity, falls within the scope of application of the EC Treaty, albeit that it is open to sport to explain and justify its practices in so far as they are necessary for its proper organisation. In short, EC law accepts that sport is 'special' - it has features, such as the need for balanced competition and uncertainty as to outcome, which are not found in typical industries - but it is not so 'special' that it can be granted a blanket exemption from the rules of the EC Treaty."125

It should be remembered that the mere position of power of a sports governing body may not, per se, lead to a finding of abuse of a dominant position. As has been observed in respect of the abuse of dominance in terms of Article 82 of the EC Treaty, ${ }^{126}$ it is not having a dominant position that is problematic, but rather the abuse of such a dominant position: "[l]t is not the power to regulate a given sporting activity as such which might constitute an abuse but rather the way in which a given sporting organization exercises such power."127

Section 8 of the Competition Act 89 of 1998, which shows marked resemblance to Article 82 of the EC Treaty, prohibits certain instances of abuse of dominance in a relevant market. Section 7 first defines the concept of dominance, as follows:

"A firm is dominant in a market if -

(a) it has at least $45 \%$ of that market;

(b) it has at least $35 \%$, but less than $45 \%$, of that market, unless it can show that it does not have market power; or

23 See the discussion in the text below.

124 Case C49/07 (judgment delivered 1 July 2008).

125 See the discussion by Weatherill "Article 82 and Sporting 'Conflict of Interest': The judgment in MOTOE' March 2009 16(2) Sport and the Law Journal 10.

126 Which prohibits any abuse by one or more undertakings of a dominant position within the common market or in a substantial part of it, which is prohibited as incompatible with such common market in so far as it may affect trade between Member States. Article 82 provides that such abuse may in particular consist of the following:

(a) directly or indirectly imposing unfair purchase or selling prices or unfair trading conditions;

(b) limiting production, markets or technical development to the prejudice of consumers;

(c) applying dissimilar conditions to equivalent transactions with other trading parties, thereby placing them at a competitive disadvantage; and

(d) making the conclusion of contracts subject to acceptance by other parties of supplementary obligations, which, by their nature or according to commercial usage, have no connection with the subject of such contracts.

127 "Commission debates application of competition rules to sport" European Commission press release dated 24 February 1999, IP/99/133 (as quoted in Lewis and Taylor B2.32). 
(c) it has less than $35 \%$ of that market, but has market power."128

It should be noted that, even if a firm satisfies any of the above requirements, the provisions of the Act relating to abuse of dominance may not be applicable to it. In terms of section 6(1) of the Act, the Minister of Trade and Industry has set a de minimis threshold; that is, the prohibition relating to abuse of dominance does not apply in respect of a firm which has an annual turnover in, into or from South Africa of below ZAR 5 million or assets in South Africa of a value below ZAR 5 million. ${ }^{129}$

In the determination of whether a firm in fact enjoys a dominant position in a market (also in terms of the above guidelines as set down in section 7), it must of course first be determined what market is involved. Unterhalter has explained this exercise as follows:

"The market is determined neither anecdotally nor impressionistically ... but according to an economic conception that treats the market as a group of products, sold (or potentially sold) in a defined area, by firms that constrain one another in a competitive process by offering products in that area that are, according to the preferences of consumers, substitutes for one another ... The definition of a market is the definition of boundaries. Those boundaries are defined across a number of dimensions. There are boundaries between products, between territorial spaces and in time."

For further discussion of the considerations that may affect the determination of the relevant market, the reader is referred to more specialized texts in this regard. ${ }^{13}$

In the context of Article 82 of the EC Treaty, the issue of dominance was considered in the case of Hoffman-La Roche \& Co AG v Commission: ${ }^{132}$

"The dominant position ... relates to a position of economic strength enjoyed by an undertaking which enables it to prevent effective competition being maintained on the relevant market by affording it the power to behave in an appreciable extent independently of its competitors, its customers and ultimately of its consumers. Such a position does not preclude some competition, which it does where there is a monopoly or quasi-monopoly, but enables the undertaking which profits by it, if not to determine, at least to have an appreciable influence on the conditions under which that competition will develop, and in any case to act largely in disregard of it so long as such conduct does not operate to its detriment."

The concept of abuse of such dominant market power is an objective one, and relates to conduct by such firm where, as a result of its presence in the

128 Lewis and Taylor 355 (B2.77) have pointed out that under UK competition law, restrictions on competition are generally considered de minimis where the parties' combined share of the relevant market does not exceed $25 \%$.

129 S 6(1); and Brassey 181.

130 Brassey 183.

$131 \mathrm{Eg}$, see the discussion in Brassey 183 et seq.

132 [1979] ECR 461.

133 See Gardiner et al 360. 
market, competition is diminished and the maintenance of the degree of competition still existing is hindered. ${ }^{134}$

Section 8 of the Act prohibits certain specific instances of abuse of a dominant position:

"It is prohibited for a dominant firm to -

(a) charge an excessive price to the detriment of consumers;

(b) refuse to give a competitor access to an essential facility when it is economically feasible to do so;

(c) engage in an exclusionary act, other than an act listed in paragraph (d), if the anti-competitive effect of that act outweighs its technological, efficiency or other pro-competitive gain; or

(d) engage in any of the following exclusionary acts, unless the firm concerned can show technological, efficiency or other pro-competitive gains which outweigh the anti-competitive effect of its act:

(i) requiring or inducing a supplier or customer to not deal with a competitor;

(ii) refusing to supply scarce goods to a competitor when supplying those goods is economically feasible;

(iii) selling goods or services on condition that the buyer purchases separate goods or services unrelated to the object of a contract, or forcing a buyer to accept a condition unrelated to the object of a contract;

(iv) selling goods or services below their marginal or average variable cost; or

(v) buying-up a scarce supply of intermediate goods or resources required by a competitor."

As Loubser has pointed out, in the sports context, potentially abusive conduct includes the collective selling of broadcasting rights, the application of non-objective entry criteria to leagues or competitions, charging excessive prices for sport-related merchandise, and selling goods or services on condition that the buyer purchases certain separate goods or services.

It is submitted - in passing - that events in the "rebel" Indian Cricket League, which is (at the time of writing) unsanctioned by the Board of Control for Cricket in India (or the "BCCI") provide some of the best current examples of the types of conduct by a sports body which might constitute abuse of a dominant position in the sporting context. Apart from the player bans that have apparently been imposed by the $\mathrm{BCCl}$ as well as other domestic cricket boards on cricketers who signed up for the ICL - which, as has been observed, might constitute abuse of dominance in terms of section

134 Loubser Chapters 8-48, with reference to Beloff et al 6.45. In Hoffman-La Roche \& Co AG v Commission [1979] ECR 461 the concept of abuse was described as follows (again in the context of the provisions of Article 82 of the EC Treaty):

"The concept of abuse is an objective concept relating to the behaviour of an undertaking in a dominant position which is such as to influence the structure of the market where, as a result of the very presence of the undertaking in question, the degree of competition is weakened and which through recourse to methods different from those which condition normal competition in products or services on the basis of transactions of commercial operators, has the effect of hindering the maintenance of the degree of competition still existing in the market or the growth of that competition."

135 Loubser Chapters 8-50. 
$4(2)$ (c) of the Indian Competition Act, $2002^{136}$ - and the BCCl's refusal to sanction the ICL, it was reported in late 2007 that the ICL was the subject of legal action in India. Zee Telefilms, the organizer and financial backer of the ICL, filed a petition against the BCCI in the Delhi High Court in August 2007 requesting an order that the $\mathrm{BCCl}$ be restrained from interfering in the ICL's signing of players as well as alleged conduct by the $\mathrm{BCCl}$ in "out-hiring" cricket stadiums in India that are owned and managed by state governments, in an attempt to prevent the ICL from staging events. The Delhi High Court granted an interim order in favour of Zee on 27 August 2007. It appears from reports that following the BCCl's banning of ICL players (which means that such players would not be able to play club cricket), there were fears that public sector undertakings such as Air India and IndianOil Corporation would dismiss their player employees who were employed for the sole purpose of playing club cricket. The Delhi High Court reportedly requested such public sector undertakings not to dismiss players. It was also reported that India's Monopolies and Restrictive Trade Practices Commission was investigating the BCCl's refusal to share infrastructure (specifically access to stadia) with the ICL. ${ }^{137}$ At the time of writing, no further information regarding the outcome of this investigation is available. It appears that this, however, is the type of conduct which would constitute abuse of a dominant position within the meaning of the above section 8 (b) of the South African Competition Act.

In the context of the organization of major events such as the football World Cup, it is difficult not to view the exclusive commercial arrangements coupled with severe restrictions on association with the event organized by a body such as FIFA as anything other than abuse of a dominant position (by the monopoly regulator of the sport, which controls the very competition and reserves for itself, from the outset, all commercial rights to the event in its founding documents) in order to stifle competition. In fact, it is submitted that the conduct of FIFA and its official partners in respect of the 2010 World Cup event raises questions regarding possible contravention of almost all of the forms of prohibited conduct as contained in section 8 of the Act. It is submitted that FIFA (and/or its commercial partners for the event) appears to have engaged in the following practices:

- Section 8(a): to charge an excessive price to the detriment of consumers - compare the reported complaints of ticket prices being fixed at unaffordable levels in respect of the local fans;

- Section 8(b): refusing to give a competitor access to an essential facility when it is economically feasible to do so - compare the sponsorship

136 As constituting conduct by an enterprise which "indulges in a practice or practices resulting in denial of market access in any manner" - see the discussion by Jha "Sports And Competition Law in India: A Critical Study with Special Reference to Cricket" July 2008 Project report prepared under the internship programme of the Competition Commission of India 10.

137 It has been suggested that such conduct by the BCCI might constitute abuse of dominance in terms of $s 4(2)$ (c) of the Indian Competition Act, 2002, in line with the "essential facility doctrine" (compare jurisprudence in the United States as discussed by Jha in fn 138 above 13-16). 
exclusivity arrangements in respect of non-sponsor products and services (sports event commercial contracts also often include "best efforts" clauses, in terms of which official sponsors and licensees undertake to purchase services or goods from other official sponsors and licensees as long as prices are competitive); compare FIFA's "clean stadia" requirements and exclusive use zones; also compare FIFA's reported restrictions on the hosting of competitions in other sporting disciplines (for example, rugby) during the period surrounding the FIFA event; ${ }^{138}$

- Section 8(d)(i): requiring or inducing a supplier or customer to not deal with a competitor - again, compare the exclusive supply arrangements and restricted access for non-sponsors to venues and fan parks ${ }^{139}$ (and possibly even the proposed Public Viewing Areas that are to be established during the FIFA event ${ }^{140}$ ); and

- Section 8(c): to engage in an exclusionary act ... if the anti-competitive effect of that act outweighs its technological, efficiency or other procompetitive gain - here, more generally, one should consider the very extensive restrictions on, for example, informal street traders as contained in host city municipal by-laws, which measures have, of course, been imposed by FIFA as a prerequisite in terms of bid guarantees. ${ }^{141}$

Kobel ${ }^{142}$ refers to the important recent European Court of Justice sporting case of Meca-Medina v EC Commission ${ }^{143}$ (which related to a challenge to a doping violation suspension) and states the following in respect of the competition law implication of sponsorship exclusivity arrangements by sports bodies:

$138 \mathrm{Eg}$, the Blue Bulls Super 14 rugby franchise, which is based at Loftus Versfeld stadium in Pretoria (a 2010 FIFA World Cup venue), was forced to play its latter games in the 2010 tournament at the Orlando football stadium in Soweto, as Loftus was handed over to FIFA a month before the start of the World Cup for its exclusive use.

139 The local host city by-laws identify fan parks, fan miles, the stadia and stadia exclusion zones, which are all subject to FIFA requirements regarding anti-ambush marketing measures.

140 It appears that, at the time of writing in early 2010, a working team of the Technical Coordinating Committee of the Department of Trade \& Industry is working on advancing coordinated implementation of Public Viewing Areas (or PVAs) in the different provinces during the FIFA event. These venues are viewed as not being "owned by FIFA", and it appears that the DTI is investigating proposals (by municipalities who experience budget constraints) to allow non-sponsors access to market and sell their products or services at such venues. At the time of writing it appears that, not surprisingly, the only issue delaying the finalization of arrangements for the PVAs is non-sponsor access, and that negotiations have been underway with FIFA and the Local Organizing Committee (which have, apparently, included a suggestion from the FIFA/LOC side to provide official sponsors with a right of first refusal in respect of marketing activities at PVAs).

141 See discussion of the host city municipal by-laws relating to the 2010 FIFA World Cup in the forthcoming Part 3 of this article.

142 Kobel "International Report on Question B: Ambush Marketing Too Smart to Be Good? Should Certain Ambush Marketing Practices Be Declared Illegal and If Yes, Which Ones and Under What Conditions?" 2007 International Report to the International League of Competition Law 47.

143 David Meca-Medina and Igor Majcen v Commission of the European Communities (Case C519/04 P; judgment delivered 18 July 2006). 
"Contrary to anti-doping rules which are pursuing legitimate objectives consisting in securing the proper conduct of a competitive sport and to ensure healthy rivalry between athletes, exclusive attribution of exclusive sponsoring rights is not inherent to the organisation of the sport competition and necessary to ensure that sporting events take place and function properly. As a result, there is a strong probability that the restraint be subject to antitrust rules."

While the preceding discussion has focused on the potential competition law implications of exclusive sponsorship and other arrangements between event organizers and their commercial partners, it is submitted that one should also in this analysis consider the potential competition law implications of anti-ambush marketing legislation passed in order to protect such commercial interests. In a recent review of ambush marketing legislation commissioned by the Australian government, the following was observed in respect of the considerations that should be borne in mind by legislatures:

"[T]here are difficulties when certain behaviour referred to as 'ambushing' appears to be little more than firms responding to changes in demand or reacting to their competitors. The difficulty is more pronounced when the said 'ambush' conduct is of type considered to be on the more benign end of the spectrum [i.e. intrusion ambushes]. There is a need to balance the interests of the organisers (assumed to require some intervention) against the interests of promoting competition in other markets (also assumed to require some intervention). This reflects an inherent conflict and inescapable trade-off between the objectives of intellectual property law and competition policy. Nevertheless, given this trade-off and the stated objects of [anti-ambush marketing legislation], one would expect that the justification for restricting competition and economic activity would be weaker where the alleged 'ambush' conduct has little impact on the value of the rights being protected or the ability of the organisers to raise revenue."

\section{The South African Constitution and Bill of Rights}

Section 2 of the South African Constitution ${ }^{145}$ provides that any law or conduct inconsistent with its provisions is invalid. South Africa enjoys what is commonly considered to be one of the most progressive constitutions in the world, and specifically boasts a progressive and comprehensive Bill of Rights, which guarantees the fundamental rights of all South Africans and affirms the democratic values of human dignity, equality and freedom. ${ }^{146}$ The Bill of Rights ${ }^{147}$ applies to all law, and is binding on the legislature, the executive, the judiciary and all organs of state. It is also binding on natural and juristic persons if, and to the extent that, it is applicable, taking into

44 Frontier Economics report (see in fn 34 above) 41.

145 Constitution of the Republic of South Africa, 1996.

146 S 7(1) of the Constitution.

147 As contained in Chapter 2 of the Constitution. For detailed discussion of the rights contained in the Bill of Rights and case law regarding its interpretation and application, the reader is referred to more specialised texts on the subject - see Currie and De Waal The Bill of Rights Handbook 5ed (2005); Cheadle, Davis and Haysom South African Constitutional Law: The Bill of Rights 2ed (2005); and Devenish The South African Constitution (2005). 
account the nature of the right and any duty imposed by the right. ${ }^{148}$ The fundamental rights as contained in the Bill of Rights may only be limited in terms of the provisions of the limitations clause contained in section 36 of the Bill of Rights, and any "limitation" of a right which does not comply with the provisions of this section will constitute an unconstitutional and invalid infringement of the applicable right. ${ }^{149}$ Every court, tribunal or forum is enjoined to promote the spirit, purport and objects of the Bill of Rights when interpreting any legislation, or when developing the common law or customary law. ${ }^{150}$ Courts are also obliged to consider international law, and may consider foreign law when interpreting the Bill of Rights. ${ }^{15}$

One must, accordingly, consider whether the South African anti-ambush marketing legislation (specifically section 15A of the Merchandise Marks Act) would pass constitutional scrutiny in terms of the applicable fundamental rights which might be impacted by the prohibitions contained in such legislation. It is submitted that the following rights as contained in the Bill of Rights are relevant here:

${ }^{148}$ Ss $8(1)$ and (2) of the Constitution. S 8 of the Bill of Rights provides as follows:

"8(1) The Bill of Rights applies to all law, and binds the legislature, the executive, the judiciary and all organs of state.

8(2) A provision of the Bill of Rights binds a natural or a juristic person if, and to the extent that, it is applicable, taking into account the nature of the right and the nature of any duty imposed by the right.

8(3) When applying a provision of the Bill of Rights to a natural or juristic person in terms of subsection (2), a court -

(a) in order to give effect to a right in the Bill, must apply, or if necessary develop, the common law to the extent that legislation does not give effect to that right; and

(b) may develop rules of the common law to limit the right, provided that the limitation is in accordance with section 36(1) [the limitation clause contained in the Bill of Rights] ..."

$149 \mathrm{~S} 36$, the limitations clause, provides as follows:

"S 36(1) The rights in the Bill of Rights may be limited only in terms of law of general application to the extent that the limitation is reasonable and justifiable in an open and democratic society based on human dignity, equality and freedom, taking into account all relevant factors, including:

(a) the nature of the right;

(b) the importance of the purpose of the limitation;

(c) the nature and extent of the limitation;

(d) the relation between the limitation and its purpose; and

(e) less restrictive means to achieve the purpose.

(2) Except as provided in subsection (1) or in any other provision of the Constitution,

no law may limit any right entrenched in the Bill of Rights."

150 S 39(2) of the Bill of Rights provides a vehicle for the "indirect" application of the Bill of Rights to disputes between private individuals or natural and juristic persons (eg, contractual disputes), and states as follows:

"When interpreting any legislation, and when developing the common law or customary law, every court, tribunal or forum must promote the spirit, purport and objects of the Bill of Rights ..." (author's own emphasis).

151 S 39(1) of the Constitution. 


\section{Freedom of expression}

Discussion in the first part of this article referred to the limitations that are placed on marketers and advertisers in respect of the promotion of their products and services with reference to major sporting events. The Merchandise Marks Act's prohibitions in this regard as contained in section 15 and, specifically, section 15A, as discussed elsewhere in this article, are indicative of the type of restrictions that are increasingly being found in antiambush marketing legislation in the various jurisdictions (although it should be noted that more than one commentator has characterized South Africa as having amongst the most stringent protection against ambush marketing in the world $\left.{ }^{152}\right)$. Of course this raises the question of whether such (commercial) speech as constituted by advertising and other promotional efforts relating to major sporting events by "ambushers" is protected in terms of the freedom of expression guarantees contained in section 16 of the Bill of Rights. ${ }^{153}$

The distinction between commercial expression (for example, in its most prominent form, namely advertising) and other forms of protected expression has apparently to a large extent been abandoned in other jurisdictions, such as the United States, ${ }^{154}$ Canada ${ }^{155}$ and India. ${ }^{156}$ In light of the wide interpretation of expression favoured by the Constitutional Court, it has been observed that all forms of commercial speech in South Africa are likely to be considered protected expression, and that any differentiation in treatment between commercial and other expression would occur at the stage of the limitations analysis in terms of section 36 of the Bill of Rights. ${ }^{157}$ In line with

152 Johnson 140; and see also Kobel 2007 International Report to the International League of Competition Law 14.

153 Compare the following (from the report by Frontier Economics (see fn 34 above) 95):

"The granting of exclusivity in the use of certain words [in anti-ambush marketing legislation] can negatively impact on the freedom of expression and political communication ... While exceptions, such as that for press reportage, are one way of dealing with this issue, there may be broader questions when legislation limiting the use of words in common usage starts to impact on free speech."

154 See Virginia State Board of Pharmacy v Virginia Citizens Consumer Council, Inc 96 S. Ct. 1817 (1976); Bates v State Bar of Arizona 433 US 350 (1978); Bigelow v Virginia 421 US 809 (1975); Central Hudson Gas v Public Services Commission 447 US 557 (1979); and Weinberg "Constitutional Protection of Commercial Speech" 198282 Columbia Law Review 720.

155 Irwin Toy Ltd v Quebec (A-G) (1989) 58 DLR $\left(4^{\text {th }}\right) 577$.

156 Tata Press Ltd v Mahangar Telephone Nigam Ltd AIR 1995 SC 2438; Hindustan Times $v$ State of UP AIR 2003 SC 250; and Sakal Papers (P) Ltd v Union of India AIR 1962 SC 305.

157 See Currie and De Waal 379. In Laugh It Off Promotions CC v South African Breweries International (Finance) BV t/a Sabmark International 20061 SA 144 (CC) Moseneke J declared the following (in par 62 of the judgment) regarding the distinction between "normal" speech and commercial speech in the context of a constitutional freedom of expression defence to parodic messages on t-shirts which incorporated adaptations of well-known trademarks (in casu, a well-known beer brand), with reference to an argument advanced by an amicus curiae in the case:

"The amicus however draws our attention to the clear duality of the roles of the Tshirts - to sell and to make a social statement. It is the expressive role, the amicus argues, which engages the constitutional protection and is worthy of its shield. To limit valuable communication to non-commercial enterprises would further 
the position elsewhere, certain limitations on the freedom of commercial expression will likely pass muster as justifiable. It is assumed that, similar to the position in other jurisdictions, one threshold requirement for commercial speech in the form of an advertisement, for example, to be constitutionally protected would be that it must not be false, deceptive or misleading to the public. ${ }^{158}$ Accordingly, and as Scaria argues, ${ }^{159}$ ambush marketers will not be able to claim constitutional protection for false and misleading advertisements. While this is undoubtedly accurate in respect of association ambush marketing, it is, however, submitted that the correctness of Scaria's conclusion that the inevitable result of bringing ambush marketing advertisements outside the purview of protection of commercial free speech is that anti-ambush marketing legislation such as the Sydney 2000 Games (Indicia and Images) Protection Act 1996 and the London Olympic Games and Paralympic Games Act 2006 will not be considered as unconstitutional on the grounds of violating commercial speech protection, ${ }^{160}$ is doubtful. The point has repeatedly been made in this article that what is known as "intrusion ambushing" - that is, for example, advertising by a non-sponsor of an event which refers to the event but without implying or causing any deception regarding association with such event ${ }^{161}-$ must be considered in

marginalise alternative and competing voices in society. In this way voices of the best resourced would tend to prevail. But also it is important to keep in mind the purpose for which the marks have been appropriated. What is being sold is not another beer or other product under the guise or on the back of the registered marks. What is being sold is rather an abstract brand criticism. T-shirts are not much more than the medium of choice."

158 Such advertisements are not constitutionally protected in the USA and India, for example see the discussion by Scaria 114-115.

159 Scaria 115.

160 Ibid.

161 See the discussion of such practices in Part 1 of this article. "Intrusion ambushes" may include a wide variety of activities which may otherwise not constitute legally or ethically objectionable conduct. An example is the marketing practice of running a promotional campaign in which tickets to an event are given away as prizes, a practice which has in recent years fell foul of anti-ambush marketing laws in a number of jurisdictions. This practice has increasingly been addressed by means of eg, contract law (ie, through the means of prohibitions contained on the tickets) or by means of specific legislation. In respect of the 2010 FIFA World Cup South Africa, the Minister of Trade \& Industry published regulations prohibiting the resale and unauthorized promotion of tickets to the event (GN 383 in GG 32123 of 2009-04-14 - such regulations to serve as additional regulations in terms of section 2A of the 2010 FIFA World Cup South Africa Special Measures Act), which provide as follows:

"(1) No person shall, without the written authority of FIFA:

(a) Sell or otherwise dispose of a 2010 FIFA World Cup South Africa ticket, or any right pertaining to such a ticket, to another person, for commercial purposes;

(b) Use a 2010 FIFA World Cup South Africa ticket for advertising, sales or promotional purposes, or as part of a hospitality or travel package, or make it available or advertise it for any such purpose;

(c) Use a ticket transferred or acquired in violation of paragraphs (a) or (b) above.

(2) Any person convicted of an offence in terms of section (1), shall be liable to a fine not exceeding R15 000.00 for each article to which the offence relates, or to imprisonment for a period not exceeding five years, or to both such fine and imprisonment." 
a different light. Where such "deception" regarding association is absent, it is submitted that an "ambush marketer" might be able to claim constitutional free speech protection. Scaria concedes this (by referring to the example of a marketer who is able to show on proper evidence that it is merely conveying information through its advertisements), although opining that "in the context of ambush marketing it is highly unlikely on the part of courts to accept such arguments". ${ }^{162}$ I would like to think that South African courts might be more open to such a finding, although the experience to date in this regard has been inconclusive (and, in author's opinion, disappointing). ${ }^{163}$

As explained elsewhere in this article, the prohibition contained in section $15 \mathrm{~A}$ of the Merchandise Marks Act is not aimed only at association ambushes, but also, more controversially, at "intrusion ambushes". An advertisement which contains use of a trademark "in relation to an event" that is "calculated to achieve publicity for such mark" and which thereby "derives special promotional benefit from the event", without the prior authority of the event organizer, is unlawful. As has been mentioned, this prohibition does not require the implication of an association with such event, ${ }^{164}$ and accordingly also covers advertising that might not necessarily be false, deceptive or misleading in any way. It is submitted that the constitutionality of the restriction on commercial speech as occasioned by section 15A would have to be assessed purely on the basis of the reasonableness and justifiability test as contained in section 36 of the Bill of Rights - an exercise that is beyond the scope of this article - which in my opinion might very likely lead to a finding that the provision constitutes an unjustifiable limitation of commercial free speech in cases of "intrusion ambush" advertising (especially where such advertising contains clear and unambiguous disclaimers denying any association with an event). It is disappointing to note that the court in FIFA $v$ Metcash Trading ${ }^{165}$ dealt only cursorily with this constitutional challenge, ${ }^{166}$ and it is submitted that the question is far from settled.

62 Ibid.

63 See the discussion of FIFA's legal challenges to ambush marketing in respect of the 2010 World Cup in section ... below. Compare also the following sentiment expressed in respect of the Canadian ambush marketing legislation in respect of the 2010 Vancouver Winter Games (by Geist "Bill C-47 Not in the Spirit of the Olympics" 19 March 2007 Toronto Star):

"[S]pecial interest legislation, particularly legislation blatantly designed to protect a select group of corporate interests at the expense of free speech, should have no place in a government focused on trust and accountability."

164 As opposed to the position under, eg, the Major Events Management Act, 2007 in New Zealand, which prohibits a "representation of association" regarding a protected event - see the discussion in par 21 above.

165 [2009] ZAGPPHC 123 - see the discussion in the forthcoming Part 3 of this article.

166 See Msimeki J's judgment (par 10):

"It has been submitted on behalf of [Metcash] that section 15A [of the Merchandise Marks Act] has to take cognisance of [Metcash's] rights to freedom of expression and 'to use its products and trademarks in the manner and get up that it chooses'. This argument, as is correctly submitted by [FIFA], loses sight of the fact that the interests of the general public must still be contended with. This ... simply means that section 36 of the Constitution would allow and justify the limitation of [Metcash's] rights to freedom of expression or to intellectual property if their use would deceive or confuse the public and end up jeopardising an event such as the soccer world cup and at the 
Apart from the inherent restrictions on advertising by non-sponsors as found in anti-ambush marketing legislative prohibitions (as discussed elsewhere in this article), it appears that major sporting events organizers have in recent times also proceeded increasingly to impose sometimes harsh and wide-ranging restrictions on the dissemination of news and information regarding such events, through the use of, for example, ticket terms and conditions, athlete-participation agreements and media accreditation regulations. During the 2000 Sydney Olympic Games athletes were prohibited from talking to their hometown newspapers or from chatting online with journalists. Video streaming of events was banned and the IOC reportedly sued 1800 "cyber-squatters" whose websites supposedly used words "owned" by the IOC. ${ }^{167}$ The IOC's rather original (although, sadly, no longer unique) approach has been characterized as the assertion of a new "centralized control over the outflow of information from the Olympic Games", and it has been observed that "the IOC wanted to be paid for staging the competitions while controlling how they would be communicated to the world: a rather novel definition of "news'". ${ }^{168}$ Others have criticised the International Rugby Board's "draconian" media accreditation regulations for the 2007 Rugby World Cup, and we also more recently saw a contretemps between FIFA and the South African media (in the form of the SA National Editors Forum) regarding the accreditation provisions for the 2010 event. It appears, at least from this observer's perspective, that the clear concerns amongst major sports federations regarding the flow of information from events goes beyond merely the need to combat commercial (ab)use of information (for example, for purposes of commercial ambush marketing campaigns); the impression is that these organizations frequently attempt to control the information purely for the sake of controlling the information. The reader is again asked to consider the fact that, in the South African jurisdiction as elsewhere, the event organizers do not enjoy a proprietary right to "the spectacle" of such event. Also, it should be noted that other branches of the law - for example, copyright law - does not protect information in the form of facts per se. ${ }^{169}$

same time prejudicing the sponsors and the licensees of the events. There is again, in my view, merit in this submission."

It is submitted, with respect, that this is a rather shockingly superficial application of the limitations exercise in s 36 of the Bill of Rights, and that Metcash's freedom of expression challenge (see par 12 of the order, where the learned judge states that it had been submitted on behalf of Metcash that s 15A has constitutional implications, and that "[t]he submission, in my view, is correct") appears to have been rejected on the basis of assumptions regarding facts and evidence which was apparently not before the court. It is submitted that deception of the public, potential "jeopardising" of the World Cup as well as prejudice to sponsors and licensees were not proved.

167 See Bollier 171.

168 See Bollier 171-172.

169 Although it should be noted that developments in some jurisdictions in respect of eg, database rights, have apparently opened the door to claims for protection of facts in terms of copyright laws - see the critical discussion by Bollier 160 et seq. Ironically, in the context of this paper, a major battleground in this respect has been sports scores and statistics (see also the recent cases in the USA regarding fantasy leagues and access to player names and statistics - compare the litigation engaged in by Major League Baseball and the NFL Players' Association). 
It is submitted that these last-mentioned developments in respect of major events may constitute a relevant factor to be considered by a court if confronted with a challenge to the constitutionality of a free-speech limitation in the context of an "intrusion ambush" advertisement, in respect of determining the reasonableness of such a limitation in the meaning of section 36(1) of the Bill of Rights.

A final aspect that merits some consideration is the issue of the South African law's treatment of parody ${ }^{170}$ in advertising, and its potential relevance in respect of ambush marketing advertising. By way of illustration of the aggressive nature of FIFA's enforcement strategy to date in respect of the 2010 event, coupled with the apparently very wide scope of the conduct which the organization views to be prohibited in terms of the South African legislation, is a promotional campaign launched by local airline kulula.com in early 2010. The airline launched a multi-media advertising campaign linked to air fares during the World Cup event, which featured advertisements with the headline "The Unofficial National Carrier of the 'You-Know-What", showing stylized drawings depicting what appears to be the new Green Point stadium in Cape Town, soccer balls, vuvuzelas, a football player and the national flag. Following a letter from FIFA's lawyers, kulula withdrew the campaign. The airline's marketing manager was quoted as stating that the advertisement had been planned to be quirky and fun, in line with the airline's reputation for tongue-in-cheek and irreverent promotional campaigns, but that it had been decided to withdraw the ad as it appears to have crossed FIFA's "very strict line" in respect of ambush marketing. It was claimed that FIFA had objected to most of what was contained in the advertisement: "They said we cannot depict the Cape Town stadium ... soccer balls ... the word South Africa, the national flag, can't make any reference to the World Cup and cannot use the vuvuzela."

In a similar vein, car manufacturer Suzuki, has also been running a promotional campaign offering "Off the Bandwagon" deals. This campaign, while not referring in any way to the 2010 World Cup event (which is probably the only reason why it has not invoked FIFA's ire), pointedly implies that the car maker is not joining all the other marketers who have climbed onto the bandwagon in respect of promoting their wares with reference to football and the World Cup: no new-car buyer will receive a free soccer ball or soccer boots.

Hewitt "Commercialisation of Major Sports Events: Does the Law Help or Hinder the Event Organiser?" 2005 13(1) Sport and the Law Journal 32-33, discusses the failed lobby in England by the Association for the Protection of Copyright in Sports for the recognition of copyright in sports events similar to other types of "works" under the applicable copyright legislation (eg, literary, artistic and musical works), which was rejected in the 1952 Gregory Report (a report of the Committee on Copyright Protection which led to the Copyright Act of 1965).

170 For an (as always) eloquent discussion of the meaning of parody, and its interaction with the law, see the judgment of Sachs $\mathrm{J}$ in the Laugh It Off case supra (especially from par 76 et seq).

171 Kulula.com marketing manager Nadine Damen, as quoted in the article by Dardagan "Kulula Flies into FIFA Flak" 19 March 2010 www.iol.co.za (accessed 2010-03-19). 
It is submitted that advertising campaigns of this nature might be justifiable as parody, although not functioning in the traditional meaning of parody as a "fair-use" defence in respect of, for example, copyright infringement. In the United States, the social value of parody has been recognized, and the courts take parody as fair-use claims seriously when considering copyright infringement claims. ${ }^{172}$ Parody can also constitute a defence to a trademark infringement claim, that is, that there is no likelihood of confusion because the parody will not be taken seriously. ${ }^{173}$

It is interesting to speculate whether section $15 \mathrm{~A}$ of the MMA leaves room for a parody defence in respect of advertising such as the kulula.com and Suzuki campaigns. While, as mentioned, the point might be moot in respect of the Suzuki campaign (in which the only conceivable "reference" to the football world cup might be the reference to soccer balls and boots), it is suggested that kulula.com may have been overhasty in pulling their campaign following FIFA's threatening stance. This brings to mind one American observer's remarks in the context of copyright: "Because of widespread misunderstanding of copyright law, cease-and-desist letters carry inordinate cultural power and can chill if not directly censor expression." ${ }^{174}$ FIFA has been sending such letters to South Africans for years. ${ }^{175}$

One online report on FIFA's response to the kulula.com campaign contained the following:

"FIFA's office told KickOff.com that their lawyers contacted Kulula drawing attention to the fact that the advert breaches SA law against ambush marketing (s.15A Merchandise Marks Act) by seeking to gain a promotional benefit for the Kulula brand by creating an unauthorised association with the 2010 FIFA World Cup."

This is, of course, drivel. As has been shown in this article, section $15 \mathrm{~A}$ is not concerned with (and does not require) the creation of or an attempt to create an "unauthorized association" with an event. The use of a mark in relation to an event which derives "special promotional benefit" for such mark does not require or refer to an association with the event. While section $15 \mathrm{~A}$ (3) provides that the use of a trademark in terms of section $15 \mathrm{~A}(2)$

172 See Campbell v Acuff-Rose Music, Inc 510 US 569 (1994), and the discussion of this case in Vaidhyanathan 146-148.

173 See the Laugh It Off case supra (and, in respect of a parody defence to trademark infringement in the context of the constitutional freedom of expression guarantee, specifically the judgment in the Constitutional Court by Sachs J).

174 Vaidhyanathan 187.

$175 \mathrm{Eg}$, in 2006 the organization admonished a local businessman who had registered five 2010 World Cup-related .co.za domains for an online travel and accommodation reservation, booking and information service (see the article by Glazier "FIFA Threatens World Cup Domain Owner" 5 October 2006 http://www.itweb.co.za (accessed 2009-04-08)). It appeared at the time that there was a lack of clarity regarding the legal position, as it appeared that FIFA's name and brand were not used, although FIFA's legal representatives were of the opinion that the domains were in contravention of the ambush marketing provisions of section 15A of the Merchandise Marks Act, in light of the "protected event" status of the 2010 World Cup. The eventual outcome of this dispute is unknown to the author at the time of writing. 
includes use of the mark "which in any way, directly or indirectly, is intended to be brought into association with or to allude to an event", the wording of the provision makes it clear that the prohibition also goes beyond such instances and is aimed at preventing non-association ambushes. It is submitted that kulula.com's advertisement did not, by any stretch of the imagination, imply an association with the World Cup. This was a clear case of the so-called "intrusion ambush" which, in fact, incorporated a disclaimer in its reference to the "unofficial" nature of its tongue-in-cheek status of national carrier for the "you-know-what". ${ }^{176}$ It is suggested that FIFA's reported justification for its muzzling of the airline (it was subsequently reported that FIFA had explained that its objection was not to use of the individual elements of the ad, but their combination) was overstated. It appears that kulula.com got the last laugh, however. Following its recall of the advertisement, kulula unveiled a new advertisement including similar elements under the following thinly-veiled reference to "2010" in a prominent heading: "Not next year, not last year, but somewhere in between". As has been observed, kulula appears to have won first prize in respect of any promotional campaign, namely the achievement of publicity. FIFA's efforts at protecting its rights in terms of the letter of the law have probably just served to bring more attention to the ad campaign than would otherwise have been the case. ${ }^{177}$

In determining the potential constitutional free-speech implications of the anti-intrusion ambush restrictions inherent in section 15A of the MMA, it is suggested that the following remarks by Moseneke $\mathrm{J}$ in the Laugh It Off case, ${ }^{178}$ regarding the dilution provisions of section 34 of the Trade Marks Act in the context of the freedom of expression guarantees in the Bill of Rights, are germane:

"The reach of the statutory prohibition [contained in s 34(1)(c) of the Trade Marks Act] must be curtailed to the least intrusive [to the constitutional guarantee] means necessary to achieve the purpose of the section. Courts must be astute not to convert the anti-dilution safeguard of renowned trademarks usually controlled by powerful financial interests into a monopoly adverse to other claims of expressive conduct of at least equal cogency and worth in our broader society" ${ }^{\text {,19 }}$ (author's own emphasis).

It is submitted here, as elsewhere in this article, that FIFA's conduct against alleged "ambush marketers" such as kulula.com, in light of legislative provisions such as section 15A of the MMA, serves to promote or maintain such a monopoly controlled by powerful financial interests which is adverse to other claims of expressive conduct, including commercial speech. It is suggested that kulula.com's exit stage left in respect of this marketing

176 Although it should be noted, of course, that the fact that $s$ 15A (2) does not require deception or confusion of the public or a representation of association with an event would make the use of a notice disclaiming such an association irrelevant for purposes of determining contravention of the provision.

177 See the article by Moerdyk "Kulula is Outwitting FIFA at Every Turn" http://www.biz community.com/Article/196/147/45942.html (accessed 2010-04-09).

178 Laugh It Off Promotions CC v South African Breweries International (Finance) B.V. t/a Sabmark International supra.

179 At par 48 of the judgment. 
campaign was premature (albeit prudent in light of the costs of potential litigation).

In conclusion on this issue, it is suggested that the very wide ambit of $\mathrm{s}$ $15 \mathrm{~A}$ serves to subject it to especially rigorous freedom of expression scrutiny as opposed to similar provisions in legislation elsewhere. The following was observed in this context in respect of the Olympic Insignia Protection Act (or "OIP Act") in Australia ${ }^{180}$

"[The OIP Act] include[s] a requirement that application [of a protected expression to goods or services] suggests to the reasonable person that there is sponsorship, sponsorship-like or other support. In addition, there are exemptions in [ambush marketing legislation], for instance for media reporting.

In theory, these might reduce any impact on freedom of expression."

As has been indicated, the provisions contained in section 15A of the MMA do not contain similar exemptions and in effect restricts a much broader spectrum of conduct and (commercial) speech.

\section{CONCLUSION}

The forthcoming third and final part of this article will continue the evaluation of the legitimacy of mega-event commercial monopolies and the antiambush marketing and other measures that are employed to protect such monopolies in light of the South African Bill of Rights. It will also evaluate the arguments raised by sports governing bodies in justification of such monopolies and consider some relevant recent developments elsewhere, with a view to considering the proper way forward in respect of future treatment of these issues in our law.

\section{(End of Part 2)}

${ }^{80}$ See discussion in par 21 above.

181 See the report of Frontier Economics (see fn 34 above) 96. 